\title{
Nutritional and medicinal benefits of Oyster (Pleurotus) mushrooms: a review
}

\author{
Galappaththi MCA ${ }^{1}$, Dauner $L^{2}$, Madawala $S^{3}$, Karunarathna $\mathrm{SC}^{2 *}$ \\ ${ }^{1}$ Postgraduate Institute of Science, University of Peradeniya, Peradeniya, Sri Lanka \\ ${ }^{2}$ Centre for Mountain Futures, Kunming Institute of Botany, Kunming, P. R. China \\ ${ }^{3}$ Department of Botany, Faculty of Science, University of Peradeniya, Peradeniya, Sri Lanka
}

Galappaththi MCA, Dauner L, Madawala S, Karunarathna SC. 2021 - Nutritional and medicinal benefits of Oyster (Pleurotus) mushrooms: a review. Fungal Biotec 1(2), 65-87, Doi 10.5943/FunBiotec/1/2/5

\begin{abstract}
Pleurotus mushrooms are the third largest commercially produced and the second most important cultivated mushroom in the world, consisting of about 539 species. This comprises $25 \%$ of total world production of cultivated mushrooms. Pleurotus mushrooms possess various nutritional and medicinal values. The fruitbodies of Pleurotus are rich in unique flavor and nutrients such as carbohydrates, protein, vitamins, minerals and dietary fibers. Bioactive compounds such as lectin, proteoglycans, laccase, lovastatin, phenols and uridine present in Pleurotus have shown some anti-tumor, anti-cancer, anti-bacterial, anti-fungal, anti-viral, antiinflammatory, genoprotective, anti-oxidant, immuno-modulatory, anti-diabetic, anti-allergic, antimitogenic, anti-hypertensive and anti-hypercholesterolemic properties. The major nutritional and medicinal benefits of important Pleurotus species are discussed in the present review.
\end{abstract}

Keywords - Amino acids - bioactive compounds - health benefits - medicinal properties minerals.

\section{Introduction}

The genus Pleurotus (Oyster mushroom) belongs to order Agaricales and family Pleurotaceae (Boa et al. 2004). About 539 Pleurotus species are present in the world (Index Fungorum 2021). It is the third largest commercially produced edible mushroom genus in the world (Singer 1986, Obodai et al. 2003). China has the highest share of Pleurotus mushroom production in the world accounting for more than $46 \%$ of the global production (Jongman et al. 2018). In last few years, Pleurotus mushroom production has increased at a rapid rate. Production of Pleurotus has increased from 876 tons to 6,288 tons (618\%) during 1997 to 2010 (Royse 2014). Pleurotus mushrooms are more popular among cultivators because of their higher biological efficiency, lowcost production methods (Mane et al. 2007), and the ability to cultivate them on a wide range of substrates (Rosado et al. 2002). Pleurotus is one of the most important commercially cultivated mushrooms in the world because of its nutritional properties, but they also possess medicinal properties and other beneficial effects that are used for various health applications (Rosado et al. 2002). Traditional medicinal properties of mushrooms in general have been well documented particularly in East Asian countries (Deepalakshmi \& Mirunalini 2014).

The genus Pleurotus has a unique flavor and aromatic properties that are rich in carbohydrates, protein, vitamins, minerals and fiber (Naraian et al. 2016). According to several 
studies, substances such as lectins, glucan, glycopeptides, $\beta$-D-Glucan (pleuran), polysaccharides and lovastatin have been identified from Pleurotus species (Cohen et al. 2002). These compounds generally act as antioxidants, immunomodulating, antitumor, antibiotic, antiviral, antiinflammatory and anticholesterolic agents (Cohen et al. 2002).

\section{Cultivation of Pleurotus mushroom}

According to Boa (2004), nearly hundred species of fungi are cultivated worldwide. Pleurotus is one of the most cultivated (Table 1) and highly popular form in commercial markets. Pleurotus is ranked as the second most cultivated mushroom in the world accounting $25 \%$ of the total world production of cultivated mushrooms (OECD, 2006). Several Pleurotus species are seen as cultivated forms in markets such as $P$. citrinopileatus, $P$. cornucopiae, $P$. cystidiosus, $P$. djamour, $P$. eryngii, P. euosmus, $P$. ostreatus, $P$. pulmonarius and $P$. rhodophyllus (Boa 2004).

China is the major producer of $P$. ostreatus and it was first cultivated in the USA in 1900. Other species such as P. sajor-caju was initially cultivated in India after the late 1940s. Pleurotus is considered as one of the most profitable cash crops in Korea (OECD, 2006).

Table 1 Commercial cultivation of Pleurotus in some countries.

\begin{tabular}{lccc}
\hline \multirow{2}{*}{ Countries } & \multicolumn{3}{c}{ Pleurotus mushroom production (Metric tons) } \\
\cline { 2 - 4 } & $\mathbf{1 9 9 1}$ & $\mathbf{1 9 9 4}$ & $\mathbf{1 9 9 8}$ \\
\hline China & 800,000 & 654,000 & - \\
Japan & 33,475 & 20,441 & - \\
USA & 695 & 900 & - \\
Indonesia & 15,000 & 1,000 & - \\
Thailand & 7,000 & 15,000 & - \\
Spain & - & 100 & - \\
Netherland & - & 150 & - \\
Italy & - & 1,500 & - \\
United Kingdom & - & 150 & - \\
Germany & - & 1,000 & - \\
France & - & 2,000 & 75,684 \\
South Korea & 51,782 & 72,810 & - \\
Taiwan & 3,500 & - & - \\
India & 600 & - & - \\
Hungary & 2,500 & - & \\
\hline
\end{tabular}

"_" Result(s) not found; Referred to OECD (2006)

\section{Nutritional value of Pleurotus species}

The nutrient contents of mushrooms vary according to the composition of the substrate (Patrabansh \& Madan 1997). Pleurotus are rich in protein, lipid, ash, carbohydrate, fiber (Table 2), minerals and vitamins (Table 4 and 5).

Table 2 Proximate composition of some Pleurotus species according to their dry weight.

\begin{tabular}{|c|c|c|c|c|c|c|}
\hline \multirow[t]{2}{*}{ Species } & \multicolumn{5}{|c|}{ Composition \% (Dry basis) } & \multirow[t]{2}{*}{ Reference } \\
\hline & Protein & $\begin{array}{l}\text { Fat or } \\
\text { Lipid }\end{array}$ & Ash & Carbohydrates & Fiber & \\
\hline \multirow[t]{5}{*}{ P. ostreatus } & $\begin{array}{l}20.33- \\
24.66\end{array}$ & $2.58-2.8$ & $6.15-6.7$ & $50.50-56.20$ & $\begin{array}{l}7.15- \\
7.7\end{array}$ & Patil et al. (2010) \\
\hline & $17-42$ & $0.5-5$ & - & $37-48$ & $24-31$ & Khan \& Tania (2012) \\
\hline & 28.40 & 4.68 & 8.60 & 35.40 & 21.80 & Ahmed et al. (2016) \\
\hline & 25.91 & 2.18 & 10.91 & 42.14 & 10.41 & Tolera \& Abera (2017) \\
\hline & 32 & 3.1 & 6.1 & 50.9 & 6.2 & Raman et al. (2020) \\
\hline \multirow[t]{2}{*}{ P. eryngii } & 11.95 & 7.50 & 4.89 & 39.85 & 28.29 & Mehmet \& Sevda (2010) \\
\hline & $11-12$ & $7-8$ & - & $39-40$ & $28-29$ & Khan \& Tania (2012) \\
\hline
\end{tabular}


Table 2 Continued.

\begin{tabular}{|c|c|c|c|c|c|c|}
\hline \multirow[t]{2}{*}{ Species } & \multicolumn{5}{|c|}{ Composition \% (Dry basis) } & \multirow[t]{2}{*}{ Reference } \\
\hline & Protein & $\begin{array}{l}\text { Fat or } \\
\text { Lipid }\end{array}$ & Ash & Carbohydrates & Fiber & \\
\hline \multirow{2}{*}{ P. sajor-caju } & 24.63 & 4.41 & 8.28 & 39.82 & 22.87 & Alam et al. (2008) \\
\hline & 25.50 & 4 & 7.23 & 38 & 25.20 & Ahmed et al. (2016) \\
\hline P. giganteus & 17.7 & 4.3 & - & 78.0 & - & Phan et al. (2012) \\
\hline \multirow[t]{4}{*}{ P. florida } & 20.56 & 4.30 & 9.02 & 42.83 & 23.29 & Alam et al. (2007) \\
\hline & $\begin{array}{l}20.25- \\
23.20\end{array}$ & $2.30-2.60$ & $\begin{array}{l}6.35- \\
8.00\end{array}$ & $53.87-57.80$ & $\begin{array}{l}7.40- \\
8.10\end{array}$ & Ahmed et al. (2009) \\
\hline & $15-21$ & $1-5$ & - & $40-43$ & $23-27$ & Khan \& Tania (2012) \\
\hline & 22.70 & 4.10 & 8.33 & 39.07 & 25.77 & Ahmed et al. (2016) \\
\hline \multirow[t]{3}{*}{ P. flabellatus } & $21-22$ & $1-2$ & - & $59-60$ & $10-12$ & Khan \& Tania (2012) \\
\hline & 27.57 & 3.70 & 7.20 & - & 24.37 & Ahmed et al. (2016) \\
\hline & 21.6 & 1.8 & 10.7 & 57.4 & 11.9 & Raman et al. (2020) \\
\hline \multirow[t]{3}{*}{ P. citrinopileatus } & 22.10 & 1.32 & 7.65 & ND & 20.78 & Musieba et al. (2013) \\
\hline & $20-22$ & 3.9 & 7.65 & 42.5 & 20.78 & Khatun et al. (2015) \\
\hline & 30 & 3.9 & 7.65 & 42.5 & 20.78 & Raman et al. (2020) \\
\hline \multirow[t]{3}{*}{ P. pulmonarius } & $\begin{array}{l}16.90- \\
26.82\end{array}$ & $1.05-2.62$ & $\begin{array}{l}5.86- \\
7.33\end{array}$ & - & $4-9$ & Silva et al. (2002) \\
\hline & $15-18$ & - & - & - & - & Khatun et al. (2015) \\
\hline & 20.3 & 2.62 & 7.33 & 34 & 9 & Raman et al. (2020) \\
\hline P. eous & 24.10 & 4.73 & 9.84 & 45.59 & 15.91 & Kortei et al. (2015) \\
\hline \multirow[t]{2}{*}{$P$. tuber regium } & 22.10 & - & 2.97 & 63.03 & 10.86 & Ijeh et al. (2009) \\
\hline & $13-17$ & $0.2-2$ & - & $53-54$ & $15-16$ & Khan \& Tania (2012) \\
\hline \multirow[t]{2}{*}{ P. cystidiosus } & 15.4 & 3.10 & 9.62 & 63.1 & 8.74 & Yang et al. (2001) \\
\hline & $17-18$ & $5-6$ & - & $43-45$ & $25-26$ & Khan \& Tania (2012) \\
\hline P. sapidus & 2.362 & 0.72 & 1.28 & 86.73 & 2.97 & Atri et al. (2016) \\
\hline \multirow{4}{*}{ P. geestaranus } & 19.0 & 3.0 & 26.3 & 45.9 & 5.7 & Khan et al. (2008) \\
\hline & 19-20 & $3-4$ & - & $45-46$ & $26-27$ & Khan \& Tania (2012) \\
\hline & 31.80 & 3.64 & 12.80 & 33.40 & 22.60 & Ahmed et al. (2016) \\
\hline & 28.80 & 3.54 & 11.20 & 31.60 & 23.00 & \\
\hline
\end{tabular}

"-" Result(s) not found

\section{Carbohydrates}

Carbohydrates are one of the most important components of mushrooms (Vaz et al. 2011) constituting between $50 \%$ and $60 \%$ of the dry matter (Kalac 2012). These mushrooms contain both high and low molecular weight carbohydrates. The high molecular weight carbohydrates are polysaccharides such as chitin and glucan. The low molecular weight carbohydrates are monosaccharides, disaccharides, and sugar alcohols (polyols), such as arabitol, glucose, mannitol, and trehalose (Zhou et al. 2016). Moreover, the carbohydrate contents of P. ostreatus are significantly affected by the method used to dry them: oven-dried $P$. ostreatus recorded a higher carbohydrate value (43.64\%) than open sun-dried mushrooms (39.99\%) (Tolera \& Abera 2017).

\section{Proteins}

There is higher protein content in mushrooms than in many vegetables (Wani et al. 2010). Also, mushrooms contain some of the essential amino acids that are often present in animal proteins. Because of these reasons, mushrooms can be consumed as an alternative to animal meat (Gonzalez et al. 2020).

Protein is a significant component of mushroom's dry weight (Table 2). The protein content of mushrooms depends on the species of the mushroom, the composition of the substrate, the 
harvesting time, and the size of pileus (Wani et al. 2010). The protein content of $P$. ostreatus is also significantly affected by the method of drying, as oven-dried $P$. ostreatus recorded a less protein content $(24.99 \%)$ than open sun-dried mushrooms (27.14\%) (Tolera \& Abera 2017). The protein content of mushrooms is also better than many common legumes such as peanuts, soybeans, and protein-yielding vegetables (Chang \& Buswell 1996, Chang \& Mshigeni 2001). Pleurotus mushrooms consist of essential and non-essential amino acids. Mushrooms are especially rich in essential amino acids (Table 3) such as lysine and leucine which are lacking in most cereal foods (Chang \& Buswell 1996).

Table 3 Amino acid composition of different mushrooms.

\begin{tabular}{|c|c|c|c|c|c|c|c|}
\hline \multirow[t]{2}{*}{ Amino acid } & \multicolumn{7}{|c|}{ mg/g dry weight } \\
\hline & $\begin{array}{l}\text { P. sajor } \\
\text { caju }\end{array}$ & $\begin{array}{l}P . \\
\text { ostreatus }\end{array}$ & $\begin{array}{l}P . \\
\text { citrinopieatus }\end{array}$ & $\begin{array}{l}\text { P. } \\
\text { eryngii }\end{array}$ & $\begin{array}{l}P . \\
\text { cystidiosus }\end{array}$ & P. florida & $\begin{array}{l}P . \\
\text { tuber- } \\
\text { regium }\end{array}$ \\
\hline Alanine & 11.24 & 28.6 & - & 8.92 & 3.94 & $4.5-5.4$ & - \\
\hline Arginine & - & 27.6 & - & - & ND & $0.1-1.0$ & - \\
\hline Aspartic acid & 20.12 & 31.4 & - & 19.55 & 0.05 & 0.3 & - \\
\hline Cystine & - & 3.8 & - & - & - & $11.6-23.8$ & - \\
\hline Glutamic acid & 15.56 & 53.3 & - & 18.48 & 1.16 & - & - \\
\hline Glycine & 9.37 & 17.1 & - & 7.48 & 0.14 & $2.6-2.9$ & - \\
\hline Histidine & - & 12.4 & - & 2.50 & ND & $0.2-21.7$ & - \\
\hline Isoleucine & 11.20 & 16.2 & $0.580-0.722$ & 7.27 & 0.23 & $2.8-27.9$ & 21.1 \\
\hline Leucine & 14.61 & 25.7 & $0.535-0.625$ & 10.77 & ND & $4.3-13.7$ & 28.4 \\
\hline Lysine & 5.75 & 22.9 & - & 7.31 & 0.32 & - & 27.4 \\
\hline Methionine & 2.72 & 3.8 & $0.321-0.500$ & - & ND & 7.6 & 4.8 \\
\hline Phenylalanine & 9.24 & 15.2 & $0.598-0.695$ & 7.16 & 0.28 & $3.6-28.9$ & 21.9 \\
\hline Proline & 7.91 & 15.2 & - & 5.86 & - & 6.0 & - \\
\hline Serine & 7.65 & 18.1 & - & 5.96 & 0.51 & - & - \\
\hline Threonine & 8.95 & 17.1 & $0.800-0.875$ & 6.78 & 0.42 & - & 31.4 \\
\hline Tyrosine & 5.96 & 13.3 & - & 4.88 & 0.05 & $2.2-22.5$ & 4.2 \\
\hline Valine & 10.04 & 21.0 & $0.930-1.035$ & 7.40 & 0.09 & $13.0-47.3$ & 33.4 \\
\hline Reference & $\begin{array}{l}\text { Dundar } \\
\text { et al. } \\
\text { (2008) }\end{array}$ & $\begin{array}{l}\text { Wang et } \\
\text { al. (2001) }\end{array}$ & $\begin{array}{l}\text { Singh \&Singh } \\
\text { (2011) }\end{array}$ & $\begin{array}{l}\text { Dundar } \\
\text { et al. } \\
\text { (2008) }\end{array}$ & $\begin{array}{l}\text { Yang et al. } \\
(2001)\end{array}$ & $\begin{array}{l}\text { Shashirekha } \\
\text { et al. (2005) }\end{array}$ & $\begin{array}{l}\text { Ahmed } \\
\text { et al. } \\
\text { (2016) }\end{array}$ \\
\hline
\end{tabular}

"_" Result(s) not found

\section{Lipids}

Generally, Pleurotus have lower fat concentrations compared to their carbohydrate and protein contents (Deepalakshmi \& Mirunalini 2014). The main fatty acid present in Pleurotus is linoleic acid (Naraian \& Bharti 2017). The relatively high concentration of linoleic acid is one of the reasons that mushrooms are considered as a nutritionally healthy food (Chang \& Mshigeni 2001, Sadler 2003). In addition to linoleic acid, there is another fatty acid common in mushrooms known as oleic acid. The variation of fat content in cultivated mushrooms depends on the type and quantity of agro-waste used for cultivation process (Ijeh et al. 2009, Raman et al. 2014, Ganesan \& $\mathrm{Xu}$ 2018). The lipid content of mushrooms also makes them a highly suitable food for humans because it has the least risk of plaque formation in blood vessels (Raman et al. 2014).

\section{Dietary fibers}

Mushrooms are a good source of dietary fibers due to the presence of polysaccharides $((1 \rightarrow$ $3)$ - $\beta$-D-glucans and mannans) and chitin (a straight chain $(1 \rightarrow 4)$ - $\beta$-linked polymer of N-acetylglucosamine) in their cell walls (Deepalakshmi \& Mirunalini 2014, Raman et al. 2020). Dietary fibers are indigestible food components which exhibit different nutritional and physiological benefits (Guillon \& Champ 2000). 


\section{Minerals}

Mineral levels (Table 4) of wild edible mushrooms are affected by the interval between the fructification and the age of mycelium. Also mineral elements are unevenly distributed within a fruitbody. Some of these elements are toxic and normally mushrooms absorb heavy metals from soil. (Kalac \& Svoboda 2000). Trace elements such as arsenic (As), barium (Ba), cobalt (Co), copper $(\mathrm{Cu})$, rubidium $(\mathrm{Rb})$, silver $(\mathrm{Ag})$, thallium $(\mathrm{Tl})$ and vanadium $(\mathrm{V})$ were observed in edible mushrooms by a study conducted in Czech Republic, South-Western Moravia, Moravský Krumlov (Svoboda \& Chrastny 2007).

Table 4 Mineral contents of dried Pleurotus mushrooms (mg / 100g).

\begin{tabular}{|c|c|c|c|c|c|c|c|c|c|c|c|}
\hline \multirow[t]{2}{*}{ Species } & \multicolumn{10}{|c|}{ Mineral Composition (mg/ 100g) } & \multirow[t]{2}{*}{ Reference } \\
\hline & $\mathbf{C a}$ & $\mathbf{F e}$ & $\mathbf{Z n}$ & Mg & Mn & Se & As & $\mathbf{P}$ & $\mathbf{N a}$ & $\mathbf{K}$ & \\
\hline \multirow[t]{3}{*}{$\begin{array}{l}\text { ostereatus } \\
\text { o. }\end{array}$} & - & 7.1 & 13.7 & 181.9 & 1.6 & - & - & 1647 & 21.9 & $\begin{array}{l}2171 . \\
4\end{array}$ & $\begin{array}{l}\text { Wang et al. } \\
(2001)\end{array}$ \\
\hline & 35.9 & 55.45 & $\begin{array}{l}26.56 \\
5\end{array}$ & $\begin{array}{l}16.39 \\
5\end{array}$ & 2.85 & 0.011 & 0.1 & - & - & - & $\begin{array}{l}\text { Alam et al. } \\
(2008)\end{array}$ \\
\hline & $2-36$ & $\begin{array}{l}55- \\
65\end{array}$ & $3-27$ & $9-17$ & $0.5-3$ & 0.011 & - & ND & 3 & 1400 & $\begin{array}{l}\text { Khan \& } \\
\text { Tania } \\
(2012)\end{array}$ \\
\hline \multirow[t]{3}{*}{ P. sajor-caju } & $\begin{array}{l}18.9- \\
36.2\end{array}$ & $\begin{array}{l}5.0- \\
11.5\end{array}$ & - & $\begin{array}{l}136- \\
188\end{array}$ & - & - & - & $\begin{array}{l}587- \\
840\end{array}$ & $\begin{array}{l}158- \\
256\end{array}$ & $\begin{array}{l}2130 \\
- \\
2400\end{array}$ & $\begin{array}{l}\text { Bano \& } \\
\text { Rajarathna } \\
\text { m (1988) }\end{array}$ \\
\hline & 22.15 & 33.45 & 20.9 & 20.22 & 2.87 & 0.025 & 0.095 & 760 & - & 3260 & $\begin{array}{l}\text { Alam et al. } \\
(2007\end{array}$ \\
\hline & $3-23$ & $\begin{array}{l}33- \\
54\end{array}$ & $3-21$ & $5-21$ & $0.5-3$ & 0.025 & - & ND & 2 & 1600 & $\begin{array}{l}\text { Khan \& } \\
\text { Tania, } \\
(2012)\end{array}$ \\
\hline \multirow[t]{2}{*}{ P. florida } & 24 & - & - & - & - & - & - & 1850 & - & 4660 & $\begin{array}{l}\text { (Bano \& } \\
\text { Rajarathna } \\
\text { m (1988) }\end{array}$ \\
\hline & 33.7 & 43.2 & 16 & 13.4 & 2.7 & $\begin{array}{l}0.013 \\
2\end{array}$ & 0.083 & - & - & - & $\begin{array}{l}\text { Alam et al. } \\
(2007)\end{array}$ \\
\hline \multirow[t]{2}{*}{ P. flabellatus } & 24 & - & - & - & - & - & - & 1550 & - & 3760 & $\begin{array}{l}\text { Bano \& } \\
\text { Rajarathna } \\
\text { m (1988) }\end{array}$ \\
\hline & 120 & 209 & 145 & 40 & 10 & ND & - & 1616 & 686 & 1537 & $\begin{array}{l}\text { Khan \& } \\
\text { Tania } \\
(2012)\end{array}$ \\
\hline \multirow[t]{2}{*}{$\begin{array}{l}P . \text { tuber } \\
\text { regium }\end{array}$} & 800 & 5.02 & 1.35 & 360 & 0.06 & $\begin{array}{l}0.002 \\
5\end{array}$ & - & - & 200 & 830 & $\begin{array}{l}\text { Ijeh et al. } \\
(2009)\end{array}$ \\
\hline & $\begin{array}{l}3- \\
200\end{array}$ & 30 & $2-2.5$ & $0.7-2$ & 2 & ND & - & $5-10$ & $2-8$ & 300 & $\begin{array}{l}\text { Khan \& } \\
\text { Tania } \\
(2012)\end{array}$ \\
\hline P. sapidus & 2.3 & 21.33 & 4.33 & 1.24 & - & - & - & - & 0.94 & 0.09 & $\begin{array}{l}\text { Atri et al. } \\
(2016)\end{array}$ \\
\hline $\begin{array}{l}P . \\
\text { citrinopieatus }\end{array}$ & 0.02 & 0.01 & 0.00 & 0.07 & - & - & - & - & 0.33 & 2.28 & $\begin{array}{l}\text { Musieba et } \\
\text { al. (2013) }\end{array}$ \\
\hline P. eryngii & 57 & 114.2 & 4.35 & - & 4.99 & - & - & - & 16.85 & 2260 & $\begin{array}{l}\text { Mehmet \& } \\
\text { Sevda } \\
(2010)\end{array}$ \\
\hline $\begin{array}{l}P . \\
\text { pulmonarius }\end{array}$ & $\begin{array}{l}0.265 \\
- \\
0.406 \\
\end{array}$ & - & - & $\begin{array}{l}0.034 \\
- \\
0.041\end{array}$ & - & - & - & - & $\begin{array}{l}0.010 \\
- \\
0.014\end{array}$ & $\begin{array}{l}0.352 \\
- \\
0.709\end{array}$ & $\begin{array}{l}\text { Adewoyin } \\
\text { \& Ayandele } \\
\text { (2018) }\end{array}$ \\
\hline
\end{tabular}




\section{Vitamins}

Pleurotus contain several vitamins (Table 5) such as Thiamine (B1), Riboflavin (B2), Niacin (B3), Folic acid (B9) and Ascorbic acid (Table 5). The folic acid present in Pleurotus helps to protect the body against anemia, high blood pressure and diabetes (Bobek et al. 1991).

Table 5 Vitamin content in some Pleurotus species (mg/100g).

\begin{tabular}{|c|c|c|c|c|c|c|}
\hline \multirow{2}{*}{ Species } & \multicolumn{5}{|c|}{ Vitamin (mg/100g) } & \multirow{2}{*}{ Reference } \\
\hline & $\begin{array}{c}\text { Thiamine } \\
\text { (B1) }\end{array}$ & $\begin{array}{c}\text { Riboflavin } \\
\text { (B2) }\end{array}$ & $\begin{array}{c}\text { Niacin } \\
\text { (B3) }\end{array}$ & $\begin{array}{c}\text { Folic acid } \\
\text { (B9) }\end{array}$ & $\begin{array}{c}\text { Ascorbic } \\
\text { acid }\end{array}$ & \\
\hline \multirow[t]{3}{*}{ P. ostreatus } & 4.8 & 4.7 & 108.7 & - & - & $\begin{array}{l}\text { Chandra \& Samsher } \\
\text { (2006) }\end{array}$ \\
\hline & 1.91 & 3.62 & 90 & - & - & Wang et al. (2001) \\
\hline & $0.29-0.35$ & $0.54-0.68$ & $\begin{array}{l}6.80- \\
9.13\end{array}$ & $\begin{array}{l}0.033- \\
0.048\end{array}$ & $\begin{array}{l}12.52- \\
15.80\end{array}$ & Patil et al. (2010) \\
\hline P. sajor caju & 1.75 & 6.66 & 60.0 & 1.278 & 111 & $\begin{array}{l}\text { Bano \& } \\
\text { Rajarathnam (1988) }\end{array}$ \\
\hline P. flabellatus & 1.46 & 7.10 & 73.3 & 1.222 & 144 & $\begin{array}{l}\text { Bano \& } \\
\text { Rajarathnam (1988) }\end{array}$ \\
\hline P. eous & 2.23 & 8.97 & 66.6 & 1.346 & 92 & $\begin{array}{l}\text { Bano \& } \\
\text { Rajarathnam (1988) }\end{array}$ \\
\hline P. florida & 1.36 & 7.88 & 72.9 & 1.412 & 113 & $\begin{array}{l}\text { Bano \& } \\
\text { Rajarathnam (1988) }\end{array}$ \\
\hline $\begin{array}{l}P . \\
\text { citrinopieatus }\end{array}$ & 0.16 & 0.94 & - & 0.097 & $<1.00$ & $\begin{array}{l}\text { Musieba et al. } \\
\text { (2013) }\end{array}$ \\
\hline $\begin{array}{l}P . \\
\text { pulmonarius }\end{array}$ & $0.35-0.68$ & $0.26-0.37$ & $\begin{array}{l}0.48- \\
0.95\end{array}$ & - & $6.17-7.53$ & $\begin{array}{l}\text { Okwulehie \& } \\
\text { Nosike (2015) }\end{array}$ \\
\hline
\end{tabular}

"_" Result(s) not found

\section{Medicinal values}

Humans have used mushrooms for medical purposes since the Neolithic and Paleolithic eras (Samorini 2001). The medicinal properties of mushrooms have valuable healthcare applications, from being used for simple conditions like skin diseases, to complex diseases like AIDS. Mushrooms also have anti-tumor, anti-cancer, anti-bacterial, anti-fungus, anti-viral, antiinflammatory, genoprotective, anti-oxidant, immuno-modulatory, anti-diabetic, anti-allergic, antimitogenic, anti-hypertensive and anti-hypercholesterolemic properties that make them valuable for treating a wide range of conditions (Table 6).

Table 6 Bioactive compounds present in some major Pleurotus species and their therapeutic properties.

\begin{tabular}{|c|c|c|c|}
\hline Species & $\begin{array}{c}\text { Bioactive } \\
\text { compound or } \\
\text { Extract }\end{array}$ & Therapeutic properties & Reference \\
\hline \multirow[t]{3}{*}{ P. pulmonarius } & $\begin{array}{l}\text { Water-soluble } \\
\text { glucans }\end{array}$ & Effect on the viability of colon cancer cells & Lavi et al. (2010) \\
\hline & $\beta$-Glucans & $\begin{array}{l}\text { Inhibited colitis-associated colon carcinogenesis } \\
\text { induced in mice }\end{array}$ & Lavi et al. (2012) \\
\hline & Methanolic extract & $\begin{array}{l}\text { Significant hydroxyl radical-scavenging and lipid } \\
\text { peroxidation-inhibiting activities }\end{array}$ & Jose et al. (2002) \\
\hline \multirow[t]{2}{*}{ P. ostreatus } & Methanolic extract & $\begin{array}{l}\text { Restored depleted antioxidant defense due to the } \\
\text { carcinogen }\end{array}$ & $\begin{array}{l}\text { Lakshmi et al. } \\
(2004)\end{array}$ \\
\hline & Methanolic extract & $\begin{array}{l}\text { Restored depleted antioxidant defense due to the } \\
\text { carcinogen }\end{array}$ & $\begin{array}{l}\text { Lakshmi et al. } \\
\text { (2004) }\end{array}$ \\
\hline
\end{tabular}


Table 6 Continued.

\begin{tabular}{|c|c|c|c|}
\hline Species & $\begin{array}{c}\text { Bioactive } \\
\text { compound or } \\
\text { Extract }\end{array}$ & Therapeutic properties & Reference \\
\hline \multirow[t]{12}{*}{ P. ostreatus } & $\begin{array}{l}\text { Polysaccharide } \\
\text { ( } \beta \text {-glucans) }\end{array}$ & $\begin{array}{l}\text { Antioxident activity, Inhibited the development of } \\
\text { a solid sarcoma } 180 \text { tumor implanted in mice, } \\
\text { Treatment of acute HSV-1 with beneficial effect } \\
\text { on the respiratory tract symptoms and infections }\end{array}$ & $\begin{array}{l}\text { Mitra et al. (2013), } \\
\text { Facchini et al. } \\
\text { (2014), } \\
\text { Urbancikova et al. } \\
(2020)\end{array}$ \\
\hline & Lectin & $\begin{array}{l}\text { Antitumor activity in mice bearing sarcoma S- } 180 \\
\text { and hepatoma H-22 }\end{array}$ & Wang et al. (2000) \\
\hline & Proteoglycans & Immunomodulators and anti-cancer agents & $\begin{array}{l}\text { Sarangi et al. } \\
(2006)\end{array}$ \\
\hline & Total Phenolic & Antioxidant activity & Yang et al. (2002) \\
\hline & Methanolic extract & $\begin{array}{l}\text { Antioxidant activity, iron chelating, reducing and } \\
\text { scavenging abilities }\end{array}$ & Yang et al. (2002) \\
\hline & Protein extract & A source of potential cancer therapeutic agents & Wu et al. (2011) \\
\hline & Mevinolin & Antihypercholesterolemic activity in rats & $\begin{array}{l}\text { Hossain et al. } \\
(2003)\end{array}$ \\
\hline & $\begin{array}{l}\text { Ergothioneine, } \\
\text { lovastatin, and } \\
\text { chrysin }\end{array}$ & Anti-atherosclerotic agents & $\begin{array}{l}\text { Abidin et al. } \\
\text { (2016) }\end{array}$ \\
\hline & Ubiquitin (Protein) & Anti-viral activities & $\begin{array}{l}\text { Wang \& Ng } \\
(2000)\end{array}$ \\
\hline & Laccase & $\begin{array}{l}\text { Inhibited hepatitis } \mathrm{C} \text { virus entry into peripheral } \\
\text { blood cells and hepatoma cells }\end{array}$ & $\begin{array}{l}\text { El-Fakharany et } \\
\text { al. }(2010)\end{array}$ \\
\hline & Lovastatin & Antihypercholesterolic & Weng et al. (2010) \\
\hline & $\begin{array}{l}\text { Water soluble } \\
\text { protein } \\
\text { /polysaccharides }\end{array}$ & Anticancer agent, Antioxident activity & $\begin{array}{l}\text { Wu et al. (2011), } \\
\text { Mitra et al. (2013) }\end{array}$ \\
\hline \multirow[t]{7}{*}{ P. eryngii } & Polysaccharides & $\begin{array}{l}\text { Enhance the antitumor activity in human hepatoma } \\
\text { cells, Antioxidant/ Immuno-Modulating effects/ } \\
\text { Hypolipidemic/Antimicrobial } \\
\text { activity }\end{array}$ & $\begin{array}{l}\text { Kim et al. (2008), } \\
\text { Kalyoncu et al. } \\
\text { (2010), } \\
\text { Reis et al. (2012), } \\
\text { Jing et al. (2013), } \\
\text { Yang et al. (2013) }\end{array}$ \\
\hline & Phenolic & Antioxidant activity & $\begin{array}{l}\text { Alam et al. (2011), } \\
\text { Choi et al. (2013) }\end{array}$ \\
\hline & $\begin{array}{l}\text { Polysaccharide } \\
\text { protein }\end{array}$ & Anticancer potential & Cui et al. (2014) \\
\hline & Methanolic extract & Antioxidant property & $\begin{array}{l}\text { Mori et al. (2008), } \\
\text { Mizutani et al. } \\
\text { (2010), } \\
\text { Li \& Shah (2013). }\end{array}$ \\
\hline & Ethanolic extract & Antimicrobial activity/Anti- Allergic Property & Han et al. (2011) \\
\hline & Water extracts & Antiviral Activity & $\begin{array}{l}\text { Nozaki et al. } \\
(2010) \text {, } \\
\text { Ike et al. (2012) }\end{array}$ \\
\hline & $\begin{array}{l}\text { Acidic } \\
\text { glycosphingolipids }\end{array}$ & Immunomodulating effect & Liu et al. (2010) \\
\hline \multirow[t]{3}{*}{ P. citrinopileatus } & Lectin & $\begin{array}{l}\text { Inhibited HIV-1 reverse transcriptase and } \\
\text { exhibited antitumor activity in mice bearing } \\
\text { sarcoma } 180\end{array}$ & (Li et al. 2008) \\
\hline & $\begin{array}{l}\text { Water soluble } \\
\text { polysaccharide }\end{array}$ & Antitumor and immuno-enhancing properties & Wang et al. (2005) \\
\hline & $\begin{array}{l}\text { Glycoprotein }(\mathrm{PCP} \\
-3 \mathrm{~A})\end{array}$ & $\begin{array}{l}\text { Growth inhibitory effect against U937 leukemia } \\
\text { cells }\end{array}$ & Chen et al. (2009) \\
\hline
\end{tabular}


Table 6 Continued.

\begin{tabular}{|c|c|c|c|}
\hline Species & $\begin{array}{c}\text { Bioactive } \\
\text { compound or } \\
\text { Extract }\end{array}$ & Therapeutic properties & Reference \\
\hline \multirow[t]{5}{*}{ P. tuber-regium } & Crude Extracts & Antifungal and antibacterial activities & $\begin{array}{l}\text { Metsebing et al. } \\
(2020)\end{array}$ \\
\hline & $\begin{array}{l}\text { Extracellular } \\
\text { polysaccharide }\end{array}$ & $\begin{array}{l}\text { Preserving hepatic cells against paracetamol- } \\
\text { induced damage in mice }\end{array}$ & $\begin{array}{l}\text { Bamigboye et al. } \\
\text { (2019) }\end{array}$ \\
\hline & $\begin{array}{l}\text { Nonstarch } \\
\text { Polysaccharide }\end{array}$ & Potential antitumor agent & $\begin{array}{l}\text { Zhang et al. } \\
(2001)\end{array}$ \\
\hline & $\begin{array}{l}\text { Hydroalcoholic } \\
\text { extracts }\end{array}$ & Antioxidant and antibacterial properties & $\begin{array}{l}\text { Adebayo et al. } \\
\text { (2018) }\end{array}$ \\
\hline & $\begin{array}{l}\text { Sulfated } \beta \text { - } \\
\text { Glucans }\end{array}$ & $\begin{array}{l}\text { Exhibited antiviral activities against HSV-1 and } \\
\text { HSV-2 }\end{array}$ & $\begin{array}{l}\text { Zhang et al. } \\
\text { (2003), Zhang et } \\
\text { al. (2004) }\end{array}$ \\
\hline \multirow[t]{5}{*}{ P. florida } & Ethanolic extract & Natural antioxidant and antimicrobial agents & $\begin{array}{l}\text { Thillaimaharani et } \\
\text { al. (2013) }\end{array}$ \\
\hline & $\begin{array}{l}\text { Myochemicals } \\
\text { (flavonoids, } \\
\text { phenolic and } \\
\text { polysaccharides) }\end{array}$ & Analgesic and anti- inflammatory potential & $\begin{array}{l}\text { Ganeshpurkar \& } \\
\text { Rai (2013). }\end{array}$ \\
\hline & Protein fraction & $\begin{array}{l}\text { Antiproliferative and immunomodulatory } \\
\text { properties }\end{array}$ & Maiti et al. (2008) \\
\hline & Lectin & $\begin{array}{l}\text { Capability of modulating arsenic mediated toxic } \\
\text { effects }\end{array}$ & Rana et al. (2012) \\
\hline & Glucan & Stimulates the phagocytic activity of macrophages & Rout et al. (2005) \\
\hline P. cornucopiae & $\begin{array}{l}\text { Laccase } \\
\text { (M.W. } 66 \mathrm{kDa})\end{array}$ & $\begin{array}{l}\text { Inhibited proliferation of murine leukemia cell line } \\
\text { L1210 and human hepatoma cell line HepG2, and } \\
\text { reduced the activity of HIV-1 reverse transcriptase }\end{array}$ & Wong et al. (2010) \\
\hline \multirow[t]{3}{*}{ P. nebrodensis } & $\begin{array}{l}\text { A novel hemolysin } \\
\text { (M.W. } \approx 27 \mathrm{kDa})\end{array}$ & $\begin{array}{l}\text { Anti-HIV-1 activity cytotoxicity against various } \\
\text { types of cancer cells }\end{array}$ & Lv et al. (2009) \\
\hline & $\begin{array}{l}\text { Methnolic and } \\
\text { acetone extracts }\end{array}$ & Antioxidant and tyrosinase inhibitory activities & Nuhu et al. (2011) \\
\hline & $\begin{array}{l}\text { Crude } \\
\text { Polysaccharides }\end{array}$ & Anticancer effect & Cha et al. (2012) \\
\hline \multirow[t]{2}{*}{ P. abalonus } & $\begin{array}{l}\text { Polysaccharides } \\
\text { (PAP) }\end{array}$ & $\begin{array}{l}\text { A potential for human colon cancer } \\
\text { chemoprevention }\end{array}$ & Ren et al. (2015) \\
\hline & $\begin{array}{l}\text { Polysaccharide- } \\
\text { peptide complex } \\
\text { (F22) }\end{array}$ & The lifespan of the mice was increased & Li et al. (2007) \\
\hline \multirow[t]{2}{*}{ P. giganteus } & $\begin{array}{l}\text { Aqueous and } \\
\text { ethanolic extracts }\end{array}$ & Neurite stimulation in rat pheochromocytoma cells & Phan et al. (2012) \\
\hline & Uridine & Responsible for neurite outgrowth & Phan et al. (2015) \\
\hline
\end{tabular}

\section{Anti-tumor and Anti-cancer activities}

Hot water extracts from the fruiting bodies of family polyporaceae exhibit host-mediated antitumor activity against Sarcoma (S-180) (Ikekawa et al. 1968), and ethanol extracts from Pleurotus also show antitumor activity towards lung cancer cells (A549) (Choi et al. 2004). The bioactive compounds such as ergosterol, glucans, aminoacids (arginine and glutamine), and proteoglucans present in Pleurotus have been correlated with antitumor activities. A possible mechanism of action of these substances is through the inhibition of neovascularization induced by the tumor growth in Sarcoma 180 cells in vitro, the activation and clonal expansion of $\mathrm{T}$ cells, increase in NK and T Helper cells and stimulation of the synthesis of interleukins, stimulation of immune function, prolonging cell survival, and promoting greater tolerance to chemotherapy 
(Fortes et al. 2006). Other examples include lactin isolated from $P$. citrinopileatus that exhibits antitumor activity in mice Sarcoma (S-180) (Li et al. 2008), and protein fractions extracted from $P$. ostreatus that show antitumor activity against different tumors of mice (Maiti et al. 2011). Different types of extracts from Pleurotus mushrooms have demonstrated anticancer abilities in different cancer cell lines and experimental animals through a number of different mechanisms of action. Water-soluble extracts of $P$. ostreatus showed the most significant cytotoxicity and induced apoptosis in human androgen-independent prostate cancer PC-3 cells (Gu \& Sivam 2006). Hot water extracts of $P$. ostreatus show inhibition in proliferation of MCF-7 human breast cancer cells (Martin \& Brophy 2010). Aqueous polysaccharide extracts of $P$. ostreatus induce pro-apoptotic and anti-proliferative effects on HT-29 colon cancer cells (Lavi et al. 2006). The methanol extracts of P. ostreatus show suppression of the proliferation of breast cancer (MCF-7, MDA-MB-231) and colon cancer (HT-29, HCT-116) cells (Jedinak \& Silva 2008). Protein extracts of P. ostreatus exhibited therapeutic efficacy against human colorectal leukemia cell lines (THP-1 cells) by inducing apoptosis in SW 450 cells (Wu et al. 2011). Lastly, water-soluble polysaccharides extracted from $P$. tuberregium also exhibit effective anti-proliferative activity against human leukemia cells by inducing apoptosis in HL-60 cells (Wong et al. 2007, Patel \& Goyal 2012).

\section{Anti-bacterial activity}

The effectiveness of mushroom antibacterial activity varies according to the solvent used to extract the compounds of mushrooms. Ethanol extracts of $P$. florida is a more effective antibacterial agent against Streptococcus sp., Escherichia coli, Klebsiella pneumonia, Salmonella typhi, Klebsiella pneumonia, Vibriocholera sp., Klebsiella oxytoca and Proteus murabilus. Petroleum ether extracts (PE) and acetone extracts of $P$. ostreatus are effective antimicrobial agents for Bacillus subtillis and Escherichia coli (Iwalokun et al. 2007).

\section{Anti-fungal activity}

Ethanol extracts of $P$. eryngii exhibit the highest antifungal activity against Candida glabrata, Candida albicans, Trichophyton spp. and Epidermophyton spp. (Akyuz \& Kirbag 2009). Thillaimaharani et al. (2013) reported that ethanol extracts of P. florida show high antifungal activity against Epidermophyton floccosum, Microsporum gypseum and Trichophyton rubrum. Petroleum ether extracts (PE) and acetone extracts of $P$. ostreatus are also effective antimicrobial agents for Saccharomyces cerevisae (Iwalokun et al. 2007). Additionally, peptides isolated from $P$. eryngii inhibit mycelial growth of Mycosphaerella arachidicola and Fusarium oxysporum (Wang $\& \mathrm{Ng} 2004)$.

\section{Antiviral activity}

Several compounds of Pleurotus show antiviral activities towards human immuno-deficiency virus/acquired immune deficiency syndrome (HIV/AIDS) (Kidukuli et al. 2010), hepatitis C virus (El-Fakharany et al. 2010), Pox virus, infectious bursa disease virus, HSV-1 (herpes simplex virus 1) and HSV-2 (Zhang et al. 2004). Methanol extracts of the $P$. sajor-caju, $P$. citrinopileatus and $P$. djamour show strong antiviral activity against HIV/AIDS (Kidukuli et al. 2010). A lactin purified from fresh fruit bodies of $P$. citrinopileatus inhibited HIV-1 reverse transcriptase with an $\mathrm{IC}_{50}$ of 22 $\mu \mathrm{M}$ (Li et al. 2008). Laccase purified from P. cornucopiae reduced the activity of HIV-1 reverse transcriptase with an $\mathrm{IC}_{50}$ of $22 \mu \mathrm{M}$. (Wong et al. 2010). Laccase present in P. eryngii inhibited the reproductive activity of influenza virus type A (serotype H1N1), and HIV-1 reverse transcriptase with an IC50 of $2.2 \mu \mathrm{M}$ (Wang \& Ng 2001). Extracts from $P$. eryngii mycelia inhibited the reproduction of influenza virus type A (serotype H1N1) (Krupodorova et al. 2014). Laccase purified from $P$. ostreatus inhibited the replication of hepatitis $C$ virus and entry into peripheral blood cells and hepatoma HepG2 cells (El-Fakharany et al. 2010). Pleurotus djamour extracts show strong antiviral activity against Poxvirus and against the Infectious bursa disease virus (Zhang et al. 2004). Lastly, antiviral activity against HSV-1 and HSV-2 was found in hot alkali-treated sclerotia of P. tuber-regium (Zhang et al. 2004). 


\section{Anti-inflammatory activity}

Inflammation is a protective response to tissue injury and is usually abates after healing (Mycek 2001). As a result of these kinds of defensive reactions, other tissue injuries may occur. In such cases, people use anti-inflammatory drugs (Mattison et al. 1988), however many currently available anti-inflammatory drugs cause side effects. Because of this, scientists are investigating the anti-inflammatory activity of mushrooms. A polysaccharide known as pleuron isolated from the fruitbodies of Pleurotus has demonstrated anti-inflammatory activity (Bobek \& Galbavy 2001, Nosál'ová et al. 2001), Lovastatin contained in Pleurotus species has exhibited anti-inflammatory activity (Alarcón et al. 2003), and Pleurotus ostreatus demonstrated protective effects on inflammatory pathologies in diabetic rats (Jayasuriya et al. 2020).

\section{Genoprotective activity and Nephroprotective activity}

Extracts of Pleurotus mushrooms exhibit DNA-protecting activities (Kim \& Kim 1999). For example, Pleurotus cornucopiae extracts significantly reduce $\mathrm{H}_{2} \mathrm{O}_{2}$-induced DNA damage in lung cells of the Chinese hamster (El-Bohi et al. 2005), and Pleurotus ostreatus suppresses DNA damage in artificially mutated Drosophila (Taira et al. 2005). Cadmium (Cd) is a highly toxic heavy metal (Yang \& Shu 2015) that is harmful to both human and animal health (Katole et al. 2013). Cadmium that is bound to proteins in kidneys causes nephropathy (Morales et al. 2006) and renal proximal tubular dysfunction due to heavy metal accumulation (Koçak \& Akçil 2006). However, Pleurotus ostreatus extract reduces the cadmium level in renal tissues and restores DNA fragmentation in rats (Dkhil 2020).

\section{Anti-oxidant activity}

Antioxidants are chemical compounds that protect the cell from damage by powerful oxidants known as free radicals. Free radicals have an ability to cause damage to compounds such as proteins, lipids, carbohydrates, and DNA, and are also involved in cancers and mutations (Przybytniak et al. 1999). According to Dubost et al. (2007), antioxidant activities of compounds are positively correlated with their total polyphenol content. Ethanol extracts of $P$. florida $(230 \mu \mathrm{g}$ equivalent of BHT/g) showed high antioxidant activity (Thillaimaharani et al. 2013). Methanol extracts of $P$. cystidiosus and $P$. ostreatus showed antioxidant activities that were higher than other commercially cultivated mushroom species (Yang et al. 2002). Internal polysaccharides and exopolysaccharides isolated from $P$. ostreatus also showed high antioxidant properties (Vamanu 2012, Elkhateeb \& Daba 2021).

\section{Immuno-modulatory activities}

Immuno-modulatory activities are modulated by cytotoxic $\mathrm{T}$ cells, activated macrophages, natural killer (NK) cells, oxygen intermediates, reactive nitrogen, tumor necrosis factors, and interleukins (Yang et al. 1992). Endo-biopolymers extracted from submerged mycelial cultures of $P$. eryngii increase the NK cell activity of splenocytes (Jeong et al. 2008). Moreover, purified acidic glycosphingolipids (AGLs) from $P$. eryngii also induce interleukin-2 (IL-2) release from invariant natural killer $\mathrm{T}$ (iNKT) cells (Nozaki 2010). Nurul et al. (2014) suggested that consumption of Pleurotus sajor-caju consistently as a daily food option may improve general immune system.

\section{Anti-diabetic activities}

Extracts of $P$. ostreatus have the ability to reduce high blood-glucose levels in hyperglycemic rats, even more so than the normal amaryl treatments (Fig. 1). Moreover, genetic alterations and sperm abnormalities were lower in $P$. ostreatus treatment groups than in the amaryl treatment groups (Ghaly et al. 2011). Pleurotus ostreatus also produces a hypoglycemic effect in alloxaninduced mice, and it has the ability to improve hyperlipidemia and impaired kidney functions (Ravi et al. 2013). 

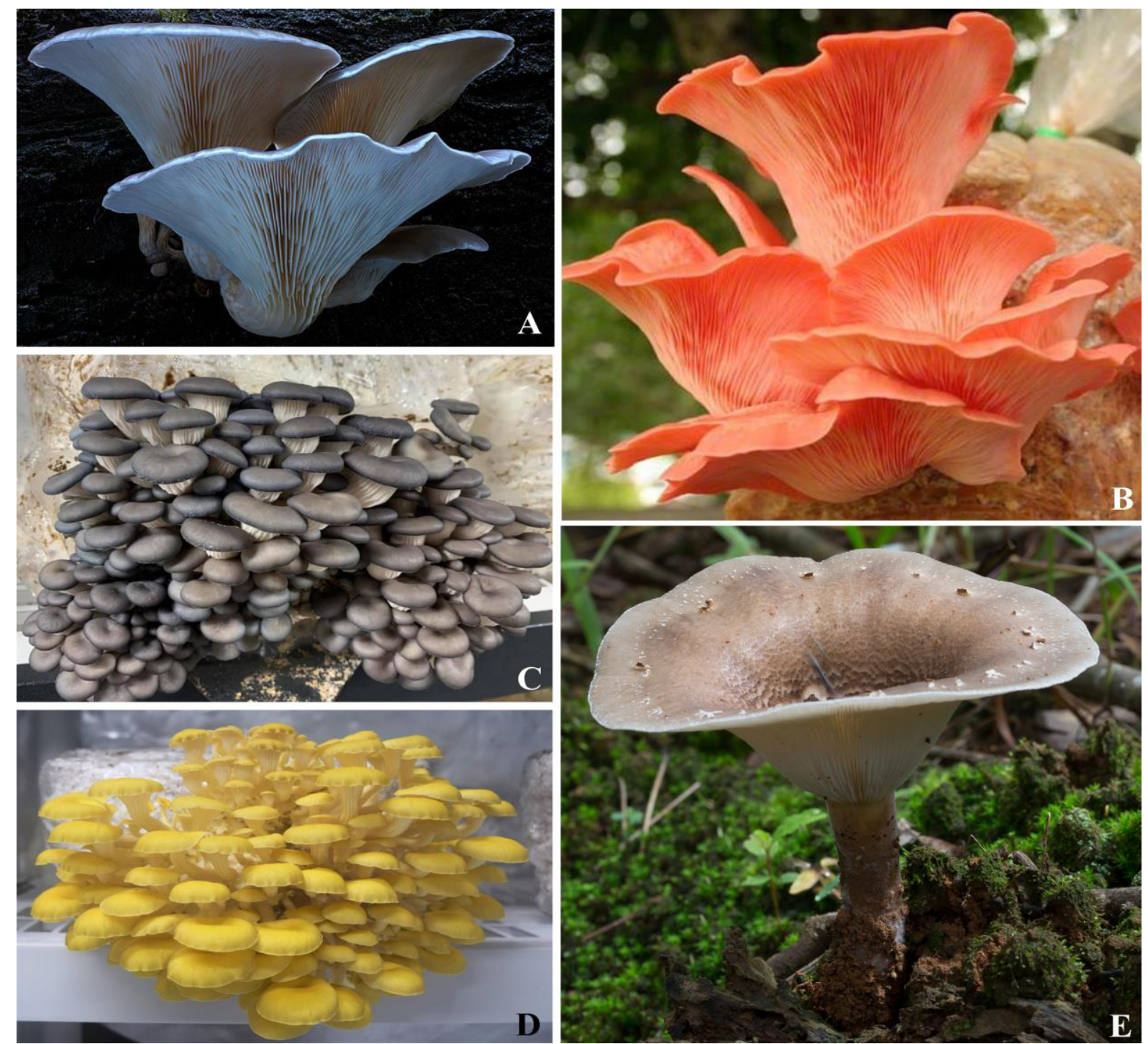

Fig. 1 - Pleurotus species: A Pleurotus purpurea-olivaceus. photo credit: Stephen Axford. B Pleurotus djamor: photo credit: Thatsanee Luangharn. C Pleurotus ostreatus: photo credit: Thatsanee Luangharn. D Pleurotus citrinopileatus: photo credit: Thatsanee Luangharn: E Pleurotus giganteus: photo credit: Samantha C. Karunarathna.

\section{Anti-allergic activities}

Extracts of $P$. eryngii inhibited atopic dermatitis (AD) skin lesions in NC/Nga mice by reducing the thickness of the dermis, and reducing dermal infiltration of inflammatory cells and mast cells (Choi et al. 2013). These extractsalso inhibited allergic contact dermatitis through the modulation of T-helper, Th1 and Th2 responses (Zhiming et al. 2016).

\section{Anti-mitogenic activities}

A ribonuclease from $P$. sajor-caju had an anti-proliferative effect on murine spleenocytes due to its terpenoids, fatty acids, steroids and phenolic compounds (Ngai \& $\mathrm{Ng} 2004$ ). Additionally, eryngeolysin derived from $P$. eryngii inhibited the accelerated mitogenic response of murine spleenocytes (Ngai \& Ng 2006).

\section{Anti-hypertensive activities}

Protein extract from $P$. cystidiosus and $P$. cornucoplae inhibited the activity of the angiotensin-1 converting enzyme (ACE), which lowers the blood pleasure, exhibiting anti- 
hypertension (Hagiwara 2005, Ching et al. 2011). Hot aqueous extracts from dried powder of $P$. nebrodensis also showed anti-hypertension activity (Miyazawa et al. 2003).

\section{Anti-hypercholesterolemic activities}

A high level of cholesterol in the blood is associated with cardiovascular disease. People with cardiovascular disease are more susceptible to heart attacks and/or strokes (Fombang et al. 2016). The ethanolic extracts of $P$. ostreatus show anti-hyperlipidamic activity in male wister rats (Opletal et al. 1997). The active substance Lovastatin present in P. ostreatus and P. sajor-caju reduces the level of triglycerides (TG) by $45 \%$ and $24 \%$ respectively, and reduced the total cholesterol (TC) level by $37 \%$ and $21 \%$ respectively (Alam et al. 2009). Moreover, polysaccharides purified from $P$. eryngii inhibit lipid accumulation in foam cells (Chen et al. 2013), and a polysaccharide known as Mevinolin present in $P$. citrinopileatus exhibits anti-hypercholesterolemic activity (GundeCimerman \& Plemenitas 2001).

\section{Applications}

In addition to medicinal and therapeutic properties, Pleurotus is an important contributor of sustainable production of functional food as Pleurotus possess an elevated protein content, essential amino acids, dietary fibres, high levels of some vitamins such as $\mathrm{B}$ group, vitamin $\mathrm{D}, \mathrm{Fe}, \mathrm{Zn}, \mathrm{Cu}$, Se and also some bioactive mycochemicals (Lavelli et al. 2018). Several studies have been carried out to check nutritional benefits of the use of dried Pleurotus species or $\beta$-glucan-rich fractions obtained from Pleurotus species as ingredients in model foods by adding Pleurotus powder into biscuits, pasta, bread, and chicken (Okafor et al. 2012, Ndung'u et al. 2015, Prodhan et al. 2015). In addition, several studies have also been carried out to replace high-cost proteins in processed meat and poultry products by using Pleurotus species (Wan-Rosli et al. 2011, Wan-Rosli \& Solihah 2012, Saiful-Bahri \& Wan-Rosli, 2016). Pleurotus species have been studied for their potential in upgrading lignocellulosic agricultural wastes for animal feed and also they are good candidates for bioremediation applications, such as soil decontamination, degradation of industrial dyes, phenols and PAHs and wastewater treatment (Cohen et al. 2002). Table 7 summarizes the applications of Pleurotus species.

Table 7 Industrial applications of Pleurotus species

\begin{tabular}{lll}
\hline Species & Application & Reference \\
\hline$P$. dryinus & $\begin{array}{l}\text { Production of lignocellulolytic } \\
\text { enzymes }\end{array}$ & Elisashvili et al. (2008) \\
$P$. & $\begin{array}{l}\text { Decolourization of industrial } \\
\text { dyes and enzymes production }\end{array}$ & Eichlerova et al. (2006) \\
$\begin{array}{l}\text { calyptratus } \\
\text { pulmonarius }\end{array}$ & $\begin{array}{l}\text { Spent Mushroom Substrate used in treatment of } \\
\text { chlorothalonil containing wastewater. }\end{array}$ & Córdova-Juárez et al. (2011) \\
$P$. ostreatus & $\begin{array}{l}\text { Biotransformation of synthetic } \\
\text { insecticide, Enzyme production and synthesis of gold } \\
\text { nanoparticles, Improvement of antioxidant } \\
\text { ability and rheological } \\
\text { properties in yogurts. }\end{array}$ & $\begin{array}{l}\text { Purnomo et al. (2013), El-Batal et } \\
\text { al. (2015), Vital et al. (2015) }\end{array}$ \\
& $\begin{array}{l}\text { Mycosynthesis and } \\
\text { characterization of silver nanoparticle }\end{array}$ & Raman et al. (2015) \\
$\begin{array}{l}\text { Par. djamor } \\
\text { roseus }\end{array}$ & $\begin{array}{l}\text { Optimization of cultural } \\
\text { condiamor }\end{array}$ & Velioglu \& Urek (2015) \\
\hline
\end{tabular}

\section{Conclusion}

This review shows that Pleurotus are rich in nutrients and they possess many promising therapeutic properties. Mushroom fruitbodies, mycelium, and their extracts are considered potential 
sources of food and have the capability to supply nutrients that are important for human health. Generally, Pleurotus are rich in protein, dietary fibers, B vitamins and are low in fat. In addition, potassium and phosphorous contents of Pleurotus are high while, Pleurotus are considered as a good source of amino acids. Pleurotus extracts have a number of bioactive compounds that can improve medicinal value and ability to synthesize drugs. In most cases, it is very important to identify the active components of Pleurotus using the best methods of extracting novel components. Once these steps have been taken, these components can finally be used for effective pharmacological and clinical treatments. Hence, Pleurotus mushrooms are a valuable asset for the welfare of humans.

\section{Conflict of interest}

No potential conflict of interest was reported by the author(s).

\section{Acknowledgments}

S.C. Karunarathna thanks CAS President's International Fellowship Initiative (PIFI) young staff under the grant number: 2020FYC0002 and the National Science Foundation of China (NSFC, project code 31851110759 ).

\section{References}

Abidin MHZ, Abdullah N, Abidin NZ. 2016 - Therapeutic properties of Pleurotus species (Oyster mushrooms) for atherosclerosis: A review. International Journal of Food Properties 20(6), 1251-1261. Doi 10.1080/10942912.2016.1210162.

Adebayo EA, Martínez-Carrera D, Morales P, Sobal M et al. 2018 - Comparative study of antioxidant and antibacterial properties of the edible mushrooms Pleurotus levis, P. ostreatus, P. pulmonarius and P. tuber-regium. International Journal of Food Science \& Technology 53(5), 1316-1330. Doi 10.1111/ijfs.13712.

Adewoyin AG, Ayandele AA. 2018 - Comparative study of yield performance and nutrient composition of the edible mushroom Pleurotus pulmonarius, cultivated on different substrates. African Journal of Plant Science 12(8), 148-154. Doi 10.5897/ajps2018.1678.

Ahmed M, Abdullah N, Nuruddin MM. 2016 - Yield and Nutritional Composition of Oyster Mushrooms: An Alternative Nutritional Source for Rural People. Sains Malaysiana 45(11), 1609-1615.

Ahmed SA, Kadam JA, Mane VP, Patil, SS, Baig, MM. 2009 - Biological Efficiency and Nutritional Contents of Pleurotus florida (Mont.) Singer Cultivated on Different Agrowastes. Nature and Science 7(1), 44-48.

Akyuz M, Kirbag S. 2009 - Antimicrobial activity of Pleurotus eryngii var. ferulae grown on various agro-wastes. EurAsian Journal of BioSciences 3, 58-63.

Alam N, Amin R, Khan A, Ara I et al. 2008 - Nutritional Analysis of Cultivated Mushrooms in Bangladesh - Pleurotus ostreatus, Pleurotus sajor-caju, Pleurotus florida and Calocybe indica. Mycobiology 36(4), 228-232. Doi 10.4489/MYCO.2008.36.4.228. PMID: 23997631; PMCID: PMC3755200.

Alam N, Amin R, Khan A, Ara I. 2009 - Comparative effects of oyster mushrooms on lipid profile, liver and kidney function in hypercholesterolemic rats. Mycobiology 37(1), 37-42. Doi 10.4489/MYCO.2009.37.1.037. PMID: 23983505; PMCID: PMC3749453.

Alam N, Khan-Hossain MS, Amin SMR, Kahn LA. 2007 - Nutritional Analysis of Dietary Mushroom- Pleurotus florida Eger and Pleurotus sajor-caju (Fr.) Singer. Bangladesh Journal of Mushroom 1(2), 1-7.

Alam N, Yoon KN, Lee JS, Cho HJ. 2011 - Dietary effect of Pleurotus eryngii on biochemical function and histology in hypercholesterolemic rats. Salman, A., Kotb, A., Ghazy, A. I., Ibrahim, E. I., \& Al-Ateeq, T. K. (2021). Corrigendum to "Structural and functional characterization of Tomato SUMO1 gene" [Saudi J. Biol. Sci. 27(1) (2020) 352-357]. Saudi 
journal of biological sciences, 28(2), 1502. Doi 10.1016/j.sjbs.2021.01.055 18(4), 403-409. Doi 10.1016/j.sjbs.2011.07.001. PMID: 23961153; PMCID: PMC3730794.

Alarcón J, Águila S, Arancibia-Avila P, Fuentes O. 2003 - Production and Purification of Statins from Pleurotus ostreatus (Basidiomycetes) Strains. Zeitschrift Für Naturforschung C 58(12), 62-64. Doi 10.1515/znc-2003-1-211.

Atri NS, Kumari B, Kumar S, Upadhyay RC, Gulati A, Lata, Gulati A. 2016 - FUNGI: applications and management strategies. Taylor \& Francis Group, LLC. pp. 373-395.

Bamigboye CO, Oloke JK, Burton M, Dames JF, Lateef A. 2019 - Optimization of the Process for Producing Biomass and Exopolysaccharide from the King Tuber Oyster Mushroom, Pleurotus tuber-regium (Agaricomycetes), for Biotechnological Applications. International journal of medicinal Mushrooms 21(4), 311-322. Doi 10.1615/IntJMedMushrooms .2019030357. PMID: 31002627.

Bano Z, Rajarathnam S. 1988 - Pleurotus mushrooms. Part II. Chemical composition, nutritional value, post-harvest physiology, preservation, and role as human food. Critical Reviews in Food Science and Nutrition 27(2), 87-158. Doi 10.1080/10408398809527480. PMID: 3053051 .

Boa E. 2004 - Wild edible fungi a global overview of their use and importance to people. Rome: FAO.

Bobek P, Galbavy S. 2001 - Effect of pleuran (beta-glucan from Pleurotus ostreatus) on the antioxidant status of the organism and on dimethylhydrazine-induced precancerous lesions in rat colon. British Journal of Biomedical Science 58(3), 164-168. PMID: 11575739.

Bobek P, Ginter E, Jurčovičová M, Kuniak L. 1991 - Cholesterol-Lowering Effect of the Mushroom Pleurotus ostreatus in Hereditary Hypercholesterolemic Rats. Annals of Nutrition and Metabolism 35(4), 191-195. Doi 10.1159/000177644.

Cha YJ, Alam N, Lee JS, Lee KR. 2012 - Anticancer and Immuno-potentiating Activities of Crude Polysaccharides from Pleurotus nebrodensis on Mouse Sarcoma 180. Mycobiology 40(4), 236-243. Doi 10.5941/MYCO.2012.40.4.236. PMID: 23323048; PMCID: PMC3538970.

Chandra S, Samsher. 2006 - Nutritional and medicinal aspects of edible mushrooms. International Journal of Agricultural Sciences 2(2), 647-651.

Chang ST, Buswell JA. 1996 - Mushroom nutriceuticals. World J Microbiol Biotechnology 12, 473-476.

Chang ST, Mshigeni KE. 2001 - Mushroom and their human health: their growing significance as potent dietary supplements. The University of Namibia, Windhoek. pp. 1-79.

Chen J, Yong Y, Xing M, Gu Y, Zhang Z, Zhang S, Lu L. 2013 - Characterization of polysaccharides with marked inhibitory effect on lipid accumulation in Pleurotus eryngii. Carbohydr Polym 97(2), 604-613. Doi 10.1016/j.carbpol.2013.05.028. PMID: 23911491.

Chen JN, Wang YT, Wu JS. 2009 - A glycoprotein extracted from golden oyster mushroom Pleurotus citrinopileatus exhibiting growth inhibitory effect against U937 leukemia cells. Journal of agricultural and food chemistry 57(15), 6706-6711. Doi 10.1021/jf901284s. PMID: 19606865.

Ching LC, Abdullah N, Shuib AS. 2011 - Characterization of antihypertensive peptides from Pleurotus cystidiosus O.K. Miller (Abalone mushroom). Proceedings of the 7th Intl Conference on Mush. Biol and Mush pp. 314-323.

Choi DB, Cha WS, Kang SH, Lee BR. 2004 - Effect of Pleurotus ferulae Extracts on Viability of Human Lung Cancer and Cervical Cancer Cell Lines. Biotechnol. Bioprocess Eng 9, 356-361.

Choi JH, Kim HG, Jin SW, Han EH, Khanal T, Do MT, Hwang YP, Choi JM, Chun SS, Chung YC, Jeong TC, Jeong HG. 2013 - Topical application of Pleurotus eryngii extracts inhibits 2,4-dinitrochlorobenzene-induced atopic dermatitis in $\mathrm{NC} / \mathrm{Nga}$ mice by the regulation of Th1/Th2 balance. Food Chemical Toxicology 53, 38-45. Doi 10.1016/j.fct.2012.11.025. PMID: 23200891. 
Cohen L, Persky Y, Hadar R. 2002 - Biotechnological applications and potential of wooddegrading mushrooms of the genus Pleurotus. Applied Microbiology and Biotechnology 58(5), 582-594. Doi 10.1007/s00253-002-0930-y.

Córdova-Juárez RA, Gordillo-Dorry LL, Bello-Mendoza R, Sánchez JE. 2011 - Use of spent substrate after Pleurotus pulmonarius cultivation for the treatment of chlorothalonil containing wastewater. Journal of Environmental Management 92(3), 948-952. Doi 10.1016/j.jenvman.2010.10.04.

Cui F, Li Y, Yang Y, Sun W. 2014 - Changes in chemical components and cytotoxicity at different maturity stages of Pleurotus eryngii fruiting body. Journal of agricultural and food chemistry 62(52), 12631-12640. Doi 10.1021/jf5048354. PMID: 25483207.

Deepalakshmi K, Mirunalini S. 2014 - Pleurotus ostreatus: an oyster mushroom with nutritional and medicinal properties. Journal of Biochemical and Molecular Toxicology 5(2), 718-726.

Dkhil MA, Diab MSM, Lokman MS, El-Sayed H, Bauomy AA, Al-Shaebi EM, Al-Quraishy S. 2020 - Nephroprotective effect of Pleurotus ostreatus extract against cadmium chloride toxicity in rats. Anais da Academia Brasileira de Ciencias 92(1), e20191121. Doi 10.1590/0001-3765202020191121. PMID: 32428092.

Dubost NJ, Ou B, Beelman RB. 2007 - Quantification of polyphenols and ergothioneine in cultivated mushrooms and correlation to total antioxidant capacity. Food Chemistry 105(2), 727-735. Doi 10.1016/j.foodchem.2007.01.030.

Dundar A, Acay H, Yildiz A. 2008 - Yield performances and nutritional contents of three oyster mushroom species cultivated on wheat stalk. African Journal of Biotechnology 7(19), 3497-3501.

Eichlerová I, Homolka L, Nerud F. 2006 - Ability of industrial dyes decolorization and ligninolytic enzymes production by different Pleurotus species with special attention on Pleurotus calyptratus, strain CCBAS 461. Process Biochemistry 41(4), 941-946. Doi 10.1016/j.procbio.2005.10.0.

El-Batal AI, El-Kenawy NM, Yassin AS, Amin MA. 2015 - Laccase production by Pleurotus ostreatus and its application in synthesis of gold nanoparticles. Biotechnology Reports 5, 31-39. Doi 10.1016/j.btre.2014.11.001.

El-Bohi KM, Sabik L, Muzandu K, Shaban Z et al. 2005 - Antigenotoxic effect of Pleurotus cornucopiae extracts on the mutagenesis of Salmonella typhimurium TA98 elicited by benzo]a[pyrene and oxidative DNA lesions in V79 hamster lung cells. Japanese Journal of Veterinary Research 52(4), 163-172. PMID: 15822858.

El-Fakharany EM, Haroun BM, Ng TB, Redwan ER. 2010 - Oyster mushroom laccase inhibits hepatitis C virus entry into peripheral blood cells and hepatoma cells. Protein and Peptide Letters 17(8), 1031-1039. Doi 10.2174/092986610791498948. PMID: 20156183.

Elisashvili V, Penninckx M, Kachlishvili E, Tsiklauri N, Metreveli E, Kharziani T, Kvesitadze G. 2008 - Lentinus edodes and Pleurotus species lignocellulolytic enzymes activity in submerged and solid-state fermentation of lignocellulosic wastes of different composition. Bioresource Technology 99(3), 457-462. Doi 10.1016/j.biortech.2007.01.

Elkhateeb WA, Daba GM. 2021 - Mycotherapy of the good and the tasty medicinal mushrooms Lentinus, Pleurotus and Tremella. Journal of Pharmacy and Pharmacology 4(3), 1-6. Doi 10.31579/2693-7247/29.

Facchini JM, Alves EP, Aguilera C, Gern RMM, Silveira MLL, Wisbeck E, Furlan SA. 2014 Antitumor activity of Pleurotus ostreatus polysaccharide fractions on Ehrlich tumor and Sarcoma 180. International Journal of Biological Macromolecules 68, 72-77. Doi 10.1016/j.ijbiomac.2014.04.033.

Fombang EN, Lobe EE, Mbofung CMF. 2016 - Pleurotus florida aqueous extracts and powder influence lipid profile and suppress weight gain in rats fed high cholesterol diet. Journal of Food Sciences and Nutrition 6, 1-7. Doi 10.4172/2155-9600.1000473

Fortes RC, Taveira VC, Novaes MRCG. 2006 - The immunomodulator role of $\beta$-D-glucans as coadjuvant for cancer therapy. Rev. Bras. Nutr. Clin 21(2), 163-168. 
Ganesan K, Xu B. 2018 - Anti-Obesity Effects of Medicinal and Edible Mushrooms. Molecules 23(11), 2880. Doi 10.3390/molecules23112880. PMID: 30400600; PMCID: PMC6278646.

Ganeshpurkar A, Rai G. 2013 - Experimental evaluation of analgesic and anti-inflammatory potential of Oyster mushroom Pleurotus florida. Indian J Pharmacol 45(1), 66-70. Doi 10.4103/0253-7613.106438. PMID: 23543896; PMCID: PMC3608298.

Ghaly IS, Ahmed ES, Booles HF, Farang I, Nada SD. 2011 - Evaluvation of antihyperglycemic action of oyster mushroom (Pleurotus ostreatus) and its effect on DNA damage, chromosome aberrations and sperm abnormalities in streptozotocin- induced diabetic rats. Global Veterinaria 7, 532-544.

Gonzalez A, Cruz M, Losoya C, Nobre C et al. 2020 - Edible Mushrooms as a Novel Protein Source for Functional Foods. Food \& Function 11(9), 7400-7414. Doi 10.1039/d0fo01746a.

Gu YH, Sivam G. 2006 - Cytotoxic effect of oyster mushroom Pleurotus ostreatus on human androgen-independent prostate cancer PC-3 cells. J Med Food 9, 196-204.

Guillon F, Champ M. 2000 - Structural and physical properties of dietary fibres, and consequences of processing on human physiology. Food Research International 33(3-4), 233-245. Doi 10.1016/s0963-9969(00)00038-7.

Gunde-Cimerman N, Plemenitas A. 2001 - Hyporcholesterolemic activity of the genus Pleurotus (Jacq.: Fr.) P. Kumm. (Agaricales s. 1., Basidiomycetes). Int J Med Mush 3, 395-397.

Hagiwara SY, Takahashi M, Shen Y, Kaihou S, Tomiyama T, Yazawa M, Tamai Y, Sin Y, Kazusaka A, Terazawa M. 2005 - A phytochemical in the edible Tamogi-take mushroom (Pleurotus cornucopiae), D-mannitol, inhibits ACE activity and lowers the blood pressure of spontaneously hypertensive rats. Biosci Biotechnol Biochem 69(8), 1603-1605. Doi 10.1271/bbb.69.1603. PMID: 16116292.

Han EH, Hwang YP, Kim HG, Choi JH, Im JH, Yang JH, Lee HU, Chun SS, Chung YC, Jeong HG. 2011 - Inhibitory effect of Pleurotus eryngii extracts on the activities of allergic mediators in antigen-stimulated mast cells. Food Chem Toxicol 49(6), 1416-1425. Doi 10.1016/j.fct.2011.03.034. PMID: 21440028.

Hossain S, Hashimoto M, Choudhury EK, Alam N, Hussain S, Hasan M, Choudhury SK, Mahmud I. 2003 - Dietary mushroom (Pleurotus ostreatus) ameliorates atherogenic lipid in hypercholesterolaemic rats. Clin Exp Pharmacol Physiol 30(7), 470-475. Doi 10.1046/j.1440-1681.2003.03857. x. PMID: 12823261.

Ijeh II, Okwujiako IA, Nwosu PC, Nnodim HI. 2009 - Phytochemical composition of Pleurotus tuber regium and effect of its dietary incorporation on body /organ weights and serum triacylglycerols in albino mice. Journal of Medicinal Plants Research 3(11), 939-943.

Ike K, Kameyama N, Ito A, Imai S. 2012 - Induction of a T-Helper 1 (Th1) immune response in mice by an extract from the Pleurotus eryngii (Eringi) mushroom. J Med Food 15(12), 1124-1128. Doi 10.1089/jmf.2012.2239. PMID: 23134464; PMCID: PMC3523248.

Ikekawa T, Nakanishi M, Uehara N, Chihara G, Fukuoka F. 1968 - Antitumor action of some Basidiomycetes, especially Phllinus linteus. Gan 59(2), 155-157. PMID: 5723060.

Index Fungorum. 2021 - Pleurotus. http://www.indexfungorum.org/names/Names.asp?pg=4 (Accessed on July 20, 2021).

Iwalokun BA, Usen UA, Otunba AA, Olukoya DK. 2007 - Comparative phytochemical evaluation, antimicrobial and antioxidant properties of Pleurotus ostreatus. African Journal of Biotechnology 6 (15), 1732-1739.

Jayasuriya WJABN, Handunnetti SM, Wanigatunge CA, Fernando GH et al. 2020 - AntiInflammatory Activity of Pleurotus ostreatus, a Culinary Medicinal Mushroom, in Wistar Rats. Evidence-Based Complementary and Alternative Medicine 2020, 1-9. Doi 10.1155/2020/6845383.

Jedinak A, Sliva D. 2008 - Pleurotus ostreatus inhibits proliferation of human breast and colon cancer cells through p53-dependent as well as p53-independent pathway. International Journal of Oncology 33, 1307-1313. 
Jeong YT, Yang BK, Li CR, Song CH. 2008 - Anti-tumor effects of exo and endo-biopolymers produced from submerged cultures of three different mushrooms. Mycobiology 36, 106-109.

Jing X, Mao D, Geng L, Xu C. 2013 - Medium optimization, molecular characterization, and bioactivity of exopolysaccharides from Pleurotus eryngii. Arch Microbiol 195(10-11), 749 757. Doi 10.1007/s00203-013-0927-1. PMID: 24071733.

Jongman M, Khare KB, Loeto D. 2018 - Oyster mushroom cultivation at different production systems: A review. European journal of Biomedical and Pharmaceutical sciences 5(5), 72-79.

Jose N, Ajith TA, Jananrdhanan KK. 2002 - Antioxidant, anti- inflammatory, and antitumor activities of culinary-medicinal mushroom Pleurotus pulmonarius (Fr.) Quel. (Agaricomycetideae). Int J Med Mush 4, 59-66. Doi 10.1615/IntJMedMushr.v4.i4.60.

Kalac P. 2012 - Chemical composition and nutritional value of European species of wild growing mushrooms. In: Andres S, Baumann N. (eds.) Mushrooms: Types, Properties and Nutrition. New York: Nova Science Publishers.

Kalac P, Svoboda L. 2000 - A review of trace element concentrations in edible mushrooms. Food Chemistry 69, 273-281.

Kalyoncu F, Oskay M, Sağlam H, Erdoğan TF, Tamer AU. 2010 - Antimicrobial and antioxidant activities of mycelia of 10 wild mushroom species. J Med Food 13(2), 415-419. Doi 10.1089/jmf.2009.0090. PMID: 20192845.

Katole S, Saha SK, Das A, Sastry VRB, Lade MH, Prakash B. 2013 - Nutrient intake, digestibility, and blood metabolites of goats fed diets containing processed jatropha meal. Tropical Animal Health and Production 45(7), 1563-1569.

Khan MA, Amin S, Uddin MN, Tania M, Alam N. 2008 - Comparative Study of the Nutritional Composition of Oyster Mushrooms Cultivated in Bangladesh. Bangladesh J. Mushroom 2(1), 9-14.

Khan MA, Tania M. 2012 - Nutritional and medicinal importance of Pleurotus mushrooms: An overview. Food Reviews International 28(3), 313-329. Doi 10.1080/87559129.2011.637267.

Khatun S, Islam A, Cakilcioglu U, Guler P, Chatterjee NC. 2015 - Nutritional qualities and antioxidant activity of three edible oyster mushrooms (Pleurotus spp.). NJAS - Wageningen Journal of Life Sciences 72-73, 1-5. Doi 10.1016/j.njas.2012.03.003.

Kidukuli AW, Mbwambo ZH, Malebo H, Mgina CA, Mihale MJ. 2010 - In vivo antiviral activity, protease inhibition and brine shrimp lethality of selected Tanzanian wild edible mushrooms. J. App. Biosci 31, 1887-1894.

Kim KC, Kim IG. 1999 - Ganoderma lucidum extract protects DNA from strand breakage caused by hydroxyl radical and UV irradiation. Int J Mol Med 4(3), 273-277. PMID: 10425278.

Kim MY, Seguin P, Ahn JK, Kim JJ. 2008 - Phenolic compound concentration and antioxidant activities of edible and medicinal mushrooms from Korea. Journal of Agricultural and Food Chemistry 56(16), 7265-7270. Doi 10.1021/jf8008553.

Koçak M, Akçıl E. 2006 - The Effects of Chronic Cadmium Toxicity on the Hemostatic System. Pathophysiology of Haemostasis and Thrombosis 35(6), 411-416. Doi 10.1159/000102047.

Kortei N, Wiafe-Kwagyan M. 2015 - Comparative Appraisal of the Total Phenolic Content, Flavonoids, Free Radical Scavenging Activity and Nutritional Qualities of Pleurotus ostreatus (EM-1) and Pleurotus eous (P-31) Cultivated on Rice (Oryzae sativa) Straw in Ghana. Journal of Advances in Biology \& Biotechnology 3, 153-164. Doi $10.9734 / \mathrm{jabb} / 2015 / 16522$.

Krupodorova T, Rybalko S, Barshteyn V. 2014 - Antiviral activity of Basidiomycete mycelia against influenza type A (serotype H1N1) and herpes simplex virus type 2 in cell culture. Virol Sin 29(5), 284-290. Doi 10.1007/s12250-014-3486-y. PMID: 25358999

Kues U, Liu Y. 2000 - Fruiting body production in basidiomycetes. Applied Microbiology and Biotechnology 54, 141-152.

Lakshmi B, Jose N, Ajith TA, Jananrdhanan KK. 2004 - Antimutagenic activity of methanolic extract of culinary-medicinal oyster mushroom, Pleurotus ostreatus (Jacq.: Fr.) Kumm. 
(strain florida Eger nom. Nud.) and its protective effect against benzo(á) pyrene-induced hepatic damages. Int J Med Mush 6, 139-149. DOI 10.1615/IntJMedMushr.v6.i2.50.

Lavelli V, Proserpio C, Gallotti F, Laureati M, Pagliarini E. 2018 - Circular reuse of bio-resources: the role of Pleurotus spp. in the development of functional foods. Food \& Function 9(3), 1353-1372. Doi 10.1039/c7fo01747b.

Lavi I, Friesem D, Geresh S, Hadar Y, Schwariz B. 2006 - An aqueous polysaccharide extract from the edible mushroom Pleurotus ostreatus induces anti-proliferative and pro-apoptotic effects on HT-29 colon cancer cells. Cancer Letters 244, 61-70.

Lavi I, Levinson D, Peri I, Tekoah Y. 2010 - Chemical characterization, antiproliferative and antiadhesive properties of polysaccharides extracted from Pleurotus pulmonarius mycelium and fruiting bodies. Applied Microbiology and Biotechnology 85(6), 1977-1990. Doi 10.1007/s00253-009-2296-x.

Lavi I, Nimri L, Levinson D, Peri I, Hadar Y, Schwartz B. 2012 - Glucans from the edible mushroom Pleurotus pulmonarius inhibit colitis-associated colon carcinogenesis in mice. Journal of Gastroenterology 47(5), 504-518. Doi 10.1007/s00535-011-0514-7.

Li L, Ng TB, Song M, Yuan F, Liu ZK, Wang CL, Jiang Y, Fu M, Liu F. 2007 - A polysaccharidepeptide complex from abalone mushroom (Pleurotus abalonus) fruiting bodies increases activities and gene expression of antioxidant enzymes and reduces lipid peroxidation in senescence-accelerated mice. Applied Microbiology and Biotechnology 75(4), 863-869. Doi 10.1007/s00253-007-0865-4. PMID: 17347821.

Li S, Shah NP. 2013 - Effects of various heat treatments on phenolic profiles and antioxidant activities of Pleurotus eryngii extracts. Journal of food science 78(8), C1122-9. Doi 10.1111/1750-3841.12189. PMID: 23957396.

Li YR, Liu QH, Wang HX, Ng TB. 2008 - A novel lectin with potent antitumor, mitogenic and HIV-1 reverse transcriptase inhibitory activities from the edible mushroom Pleurotus citrinopileatus. Biochimica et Biophysica Acta 1780(1), 51-57. Doi 10.1016/j.bbagen.2007.09.004. PMID: 17961926.

Liu X, Zhou B, Lin R, Jia L. 2010 - Extraction and antioxidant activities of intracellular polysaccharide from Pleurotus sp. mycelium. Int J Biol Macromol 47(2), 116-119. Doi 10.1016/j.ijbiomac.2010.05.012. PMID: 20580645.

Lv H, Kong Y, Yao Q, Zhang B. 2009 - Nebrodeolysin, a novel hemolytic protein from mushroom Pleurotus nebrodensis with apoptosis-inducing and anti-HIV-1 effects. Phytomedicine 16(23), 198-205. Doi 10.1016/j.phymed.2008.07.004. PMID: 18722099.

Maiti S, Bhutia SK, Mallick SK, Kumar A, Khadgi N, Maiti TK. 2008 - Antiproliferative and immunostimulatory protein fraction from edible mushrooms. Environ Toxicol Pharmacol 26(2), 187-191. Doi 10.1016/j.etap.2008.03.009. PMID: 21783909.

Maiti S, Mallick SK, Bhutia SK, Behera B, Mandal M, Maiti TK. 2011 - Antitumor effect of culinary-medicinal oyster mushroom, Pleurotus ostreatus (Jacq.: Fr.) P. Kumm., derived protein fraction on tumor-bearing mice models. International Journal of Medicinal Mushrooms 13(5), 427-440. Doi 10.1615/intjmedmushr.v13.i5.20. PMID: 22324408.

Mane VP, Patil SS, Syed AA, Baig MMV. 2007 - Bioconversion of low quality lignocellulosic agricultural waste into edible protein by Pleurotus sajor-caju (Fr.) singer. Journal of Zhejiang University SCIENCE B 8(10), 745-751. Doi 10.1631/jzus.2007.b0745.

Martin KR, Brophy SK. 2010 - Commonly consumed and specialty dietary mushrooms reduce cellular proliferation in MCF-7 human breast cancer cells. Experimental Biology and Medicine 235, 1306-1314.

Mattison N, Trimble AG, Lasagna L. 1988 - New drug development in the United States, 1963 through 1984. Clinical Pharmacology and Therapeutics 43(3), 290-301. Doi 10.1038/clpt.1988.35. PMID: 3278822.

Mehmet A, Sevda K. 2010 - Effect of various agro-residues on nutritive value of Pleurotus eryngii (DC. ex Fr.) Quel. var. ferulae Lanzi. The Journal of Agricultural Science 16, 83-88. 
Metsebing BP, Oba R, Mossebo DC, Fonkui TY et al. 2020 - Comparative Assessment of Antifungal and Antibacterial Activities of Crude Extracts of the King Tuber CulinaryMedicinal Mushroom, Pleurotus tuber-regium (Agaricomycetes) from Cameroon. International Journal of Medicinal Mushrooms 22(4), 359-366. Doi 10.1615/IntJMedMushrooms. PMID: 32558500.

Mitra P, Khatua S, Acharya K. 2013 - Free radical scavenging and NOS activation properties of water-soluble crude polysaccharides from Pleurotus ostreatus. Asian journal of pharmaceutical and clinical research 6(3), 67-70.

Miyazawa N, Eguchi F, Kitazima Y, Kitamoto Y. 2003 - Proceeding of Japanese Society of Mushroom Science and Biotechnology Congress, Gumma. pp. 37.

Mizutani T, Inatomi S, Inazu A, Kawahara E. 2010 - Hypolipidemic effect of Pleurotus eryngii extract in fat-loaded mice. Journal of Nutritional Science and Vitaminology (Tokyo) 56(1), 48-53. Doi 10.3177/jnsv.56.48. PMID: 20354346.

Morales AI, Vicente-Sánchez C, Sandoval JM, Egido J, Mayoral P, Arévalo MA, FernándezTagarro M, López-Novoa JM, Pérez-Barriocanal F. 2006 - Protective effect of quercetin on experimental chronic cadmium nephrotoxicity in rats is based on its antioxidant properties. Food Chem Toxicol 44(12), 2092-2100. Doi 10.1016/j.fct.2006.07.012. PMID: 16962696.

Mori K, Kobayashi C, Tomita T, Inatomi S, Ikeda M. 2008 - Antiatherosclerotic effect of the edible mushrooms Pleurotus eryngii (Eringi), Grifola frondosa (Maitake), and Hypsizygus marmoreus (Bunashimeji) in apolipoprotein E-deficient mice. Food Science and Nutrition 28(5), 335-342. Doi 10.1016/j.nutres.2008.03.010. PMID: 19083429.

Musieba F, Okoth S, Mibey RK, Vanjiku S, Moraa K. 2013 - Proximate composition, amino acids and vitamins profile of Pleurotus citrinopileatus Singer: an indigenous mushroom in Kenya. Am J Food Technol 8(3), 200-206.

Mycek MJ, Harvvey RA, Champe PC. 2001 - Anti-inflammatory drugs and autacoids. In: Harvvey R, Champe PC. (eds.) Lippincott's Illustrated Reviews: Pharmacology. Lippincott Williams and Wilkins, Pennsylvania, PA, USA. pp. 401.

Naraian R, Dixit B. 2017 - Nutritional Value of Three Different Oyster Mushrooms Grown on Cattail Weed Substrate. Arch Biotechnol Biomed 1, 061-066. DOI 10.29328/journal.hjb.1001006.

Naraian R, Singh MP, Ram S. 2016 - Supplementation of basal substrate to boost up substrate strength and oyster mushroom yield: an overview of substrates and supplements. Int J Curr Microbiol App Sci 5, 543-553.

Ndung'u SW, Otieno CA, Onyango C, Musieba F. 2015 - Nutritional composition, physical qualities and sensory evaluation of wheat bread supplemented with oyster mushroom. Am. J. Food Technol 10, 241-253.

Ngai PH, Ng TB. 2004 - A ribonuclease with antimicrobial, antimitogenic and antiproliferative activities from the edible mushroom Pleurotus sajor-caju. Peptides 25(1), 11-17. Doi 10.1016/j.peptides.2003.11.012. PMID: 15003351.9.

Nosál'ová V, Bobek P, Cerná S, Galbavý S, Stvrtina S. 2001 - Effects of pleuran (beta-glucan isolated from Pleurotus ostreatus) on experimental colitis in rats. Physiol Res 50(6), 575-581. PMID: 11829318.

Nozaki H, Itonori S, Sugita M, Nakamura K. 2010 - Invariant Valpha14 natural killer T cell activation by edible mushroom acidic glycosphingolipids. Biol Pharm Bull 33(4), 580-584. Doi 10.1248/bpb.33.580. PMID: 20410589.

Nuhu A, Ki NY, Tae SL. 2011 - Evaluation of the antioxidant and antityrosinase activities of three extracts from Pleurotus nebrodensis fruiting bodies. African Journal of Biotechnology 10(15), 2978-2986. Doi 10.5897/ajb10.2660.

Nurul AA, Johnathan M, Jamaruddin MA, Rosli WW. 2014 - Immunomodulatory Effects of Oyster Mushroom (Pleurotus sajor-caju) Extract In Balb/c Mice. Research and reviews: Journal of Pharmacy and Pharmaceutical Sciences 3(3), 27-32. 
Obodai M, Cleland-Okine J, Vowotor K. 2003 - Comparative study on the growth and yield of Pleurotus ostreatus mushroom on different lignocellulosic by-products. Journal of Industrial Microbiology and Biotechnology 30(3), 146-149.

OECD. 2006 - Section 11 - Oyster Mushroom (Pleurotus spp.)", in Safety Assessment of Transgenic Organisms, Volume 1. OECD Consensus Documents, OECD Publishing, Paris. pp. 277-292. Doi 10.1787/9789264095380-14-en.

Okafor NC, Okafor GI, Ozumba AU, Elemo GN. 2012 - Quality characteristics of bread made from wheat and Nigerian oyster mushroom (Pleurotus plumonarius) powder. Pak. J. Nutr 11, $5-10$.

Okwulehie IC, Nosike EN. 2015 - Phytochemicals and vitamin compositions of Pleurotus pulmonarius cultivated on barks of some indigenous fruit trees supplemented with agrowastes. Asian J Plant Sci 5(2), 1-7.

Opletal L, Jahodar L, Chobot V, Zdansky P et al. 1997 - Evidence for the antihyperlipidaemic activity of edible fungus Pleurotus ostreatus. Br. J. Biomed. Sci 54, 240-243.

Patel S, Goyal A. 2012 - Recent developments in mushrooms as anticancer therapeutics: a review. 3 Biotech 2(1), 1-15.

Patil SS, Ahmed SA, Telang S, Beig MM. 2010 - The nutritional value of Pleurotus ostreatus (jacq.:fr.) kumm cultivated on different lignocellulosic agrowastes. Innovative Romanian Food Biotechnology 7, 66-76.

Patrabansh S, Madan M. 1997 - Studies on cultivation, biological efficiency and chemical analysis of Pleurotus sajor-caju (FR.) SINGER on different bio-wastes. Acta Biotechnologica 17(2), 107-122. Doi 10.1002/abio.370170202.

Phan CW, David P, Wong KH, Naidu M, Sabaratnam V. 2015 - Uridine from Pleurotus giganteus and Its Neurite Outgrowth Stimulatory Effects with Underlying Mechanism. PLoS One 10(11), 1-16. Doi 10.1371/journal.pone.0143004. PMID: 26565787; PMCID: PMC4643974.

Phan CW, Wong WL, David P, Naidu M, Sabaratnam V. 2012 - Pleurotus giganteus (Berk.) Karunarathna \& K.D. Hyde: Nutritional value and in vitro neurite outgrowth activity in rat pheochromocytoma cells. BMC Complement Altern Med 12, 102. Doi 10.1186/1472-688212- 102. PMID: 22812497; PMCID: PMC3416657.

Prodhan UK, Linkon KMMR, Al-Amin MF, Alam MJ. 2015 - Development and quality evaluation of mushroom (Pleurotus sajor-caju) enriched biscuits. Emirates J. Food Agric 27, 542-547.

Przybytniak G, Ambroz H. 1999 - Free radicals, their identification and determination. In: Marciniec B, Zak S. (eds.) Analytical methods in studies of pollutants and hazardous. Bydgoszcz: BTN. pp. 17.

Purnomo AS, Mori T, Putra SR, Kondo R. 2013 - Biotransformation of heptachlor and heptachlor epoxide by white-rot fungus Pleurotus ostreatus. International Biodeterioration \& Biodegradation 82, 40-44. Doi 10.1016/j.ibiod.2013.02.013.

Raman J, Jang KY, Oh YL, Oh M. 2020 - Cultivation and Nutritional Value of Prominent Pleurotus spp.: An Overview. Mycobiology 49(1), 1-14. Doi 10.1080/12298093.2020.1835142.

Raman J, Nanjian R, Lakshmanan H, Ramesh V, Srikumar R. 2014 - Hypolipidemic effect of Pleurotus djamor var. roseus in experimentally induced hypercholesteromic rats. Res J Pharm Biol Chem Science 5(2), 581-588.

Raman J, Reddy GR, Lakshmanan H, Selvaraj V. 2015 - Mycosynthesis and characterization of silver nanoparticles from Pleurotus djamor var. roseus and their in vitro cytotoxicity effect on PC3 cells. Process Biochemistry 50(1), 140-147. Doi 10.1016/j.procbio.2014.11.0.

Rana T, Bera AK, Das S, Bhattacharya D et al. 2012 - Pleurotus florida lectin normalizes duration dependent hepatic oxidative stress responses caused by arsenic in rat. Exp Toxicol Pathol 64(7-8), 665-671. Doi 10.1016/j.etp.2010.12.010. PMID: 21227667.

Ravi B, Renitta RE, Praba ML, Issac R, Naidu S. 2013 - Evaluation of antidiabetic potential of oyster mushroom (Pleurotus ostreatus) in alloxan-induced diabetic mice. Immunopharmacol Immunotoxicol 35(1), 101-109. Doi 10.3109/08923973.2012.710635. PMID: 22867521. 
Reis FS, Martins A, Barros L, Ferreira IC. 2012 - Antioxidant properties and phenolic profile of the most widely appreciated cultivated mushrooms: a comparative study between in vivo and in vitro samples. Food and Chemical Toxicology 50(5), 1201-1207. Doi 10.1016/j.fct.2012.02.013. PMID: 22369965.

Ren D, Jiao Y, Yang X, Yuan L. 2015 - Antioxidant and antitumor effects of polysaccharides from the fungus Pleurotus abalonus. Chemico-Biological Interactions 237, 166-174. Doi 10.1016/j.cbi.2015.06.017.

Rosado FR, Carbonero ER, Kemmelmeier C, Tischer CA. 2002 - A partially 3-O-methylated (1->4)-linked alpha-D-galactan and alpha-D-mannan from Pleurotus ostreatoroseus Sing. FEMS microbiology letters 212(2), 261-265. Doi 10.1111/j.1574-6968.2002.tb11276.x. PMID: 12113944.

Rout D, Mondal S, Chakraborty I, Pramanik M, Islam SS. 2005 - Chemical analysis of a new (1-$>3)-$, (1-->6)-branched glucan from an edible mushroom, Pleurotus florida. Carbohydrate Researchs 340(16), 2533-2539. Doi 10.1016/j.carres.2005.08.006. PMID: 16169534.

Royse DJ. 2014 - A global perspective on the high five: Agaricus, Pleurotus, Lentinula, Auricularia \& Flammulina. In Proceedings of the 8th International Conference on Mushroom Biology and Mushroom Products (ICMBMP8), (Vol. 1), pp. 1-6.

Sadler M. 2003 - Nutritional properties of edible fungi. Nutrition Bulletin 28(3), 305-308. Doi 10.1046/j.1467-3010.2003.00354.x.

Saiful-Bahri S, Wan-Rosli WI. 2016 - Effect of oyster mushroom (Pleurotus sajor-caju) addition on the nutritional composition and sensory evaluation of herbal seasoning. International food research journal 23, 262-268.

Samorini G. 2001 - Fungi Hallucinogeni. In: Guo J, Cheng HY, Wei X. (eds.) Studi etnomicologici. Telesterion. Dozza Ed., Bologna, Italy, Shen. pp. 250.

Sarangi I, Ghosh D, Bhutia SK, Mallick SK, Maiti TK. 2006 - Anti-tumor and immunomodulating effects of Pleurotus ostreatus mycelia-derived proteoglycans. International Immunopharmacology 6(8), 1287-1297. Doi 10.1016/j.intimp.2006.04.002. PMID: 16782541.

Shashirekha M, Rajarathnam S, Bano Z. 2005 - Effects of Supplementing rice straw growth substrate with cotton seeds on the Analytical characteristics of the Mushroom, (block \&; tsao). Food Chemistry 92(2), 255-259. Doi 10.1016/j.foodchem.2004.07.034.

Silva SO, Costa SMG da, Clemente E. 2002 - Chemical composition of Pleurotus pulmonarius (Fr.) Quél., substrates and residue after cultivation. Brazilian Archives of Biology and Technology 45(4), 531-535. Doi 10.1590/s1516-89132002000600018.

Singer R. 1986 - The Agaricales in modern taxonomy. Koeltz Scientific Books, Koenigstein.

Singh MP, Singh VK. 2011 - Yield Performance and Nutritional Analysis of Pleurotus citrinopileatus on Different Agrowastes and Vegetable Wastes. Proceedings of the 7th International Conference on Mushroom Biology and Mushroom Products (ICMBMP7) $385-392$.

Svoboda L, Chrastny V. 2007 - Contents of eight trace elements in edible mushrooms from a rural area. Food Additives and Contaminants 25 (1), 51-58.

Taira K, Miyashita Y, Okamoto K, Arimoto S et al. 2005 - Novel antimutagenic factors derived from the edible mushroom Agrocybe cylindracea. Mutation Research 586(2), 115-123. Doi 10.1016/j.mrgentox.2005.06.007. PMID: 16095952.

Thillaimaharani KA, Sharmila K, Thangaraju P, Karthick M, Kalaiselvam M. 2013 - Studies on Antimicrobial and Antioxidant properties of Oyster Mushroom Pleurotus florida. International Journal of Research in Pharmaceutical Sciences 4(4), 1540-1545.

Tolera KD, Abera S. 2017 - Nutritional quality of Oyster Mushroom (Pleurotus Ostreatus) as affected by osmotic pretreatments and drying methods. Food Science and Nutrition 5(5), 989-996. Doi 10.1002/fsn3.484. PMID: 28948016; PMCID: PMC5608979.

Urbancikova I, Hudackova D, Majtan J, Rennerova Z. 2020 - Efficacy of Pleuran ( $\beta$-Glucan from Pleurotus ostreatus) in the Management of Herpes Simplex Virus Type 1 Infection. 
Evidence-Based Complementary and Alternative Medicine 2020, 1-8. Doi 10.1155/2020/8562309.

Vamanu E. 2012 - Biological Activities of the Polysaccharides Produced in Submerged Culture of Two Edible Pleurotus ostreatus Mushrooms. Journal of Biomedicine and Biotechnology 2012, 1-8. Doi 10.1155/2012/565974.

Vaz JA, Barros L, Martins A, Santos-Buelga C. 2011 - Chemical composition of wild edible mushrooms and antioxidant properties of their water soluble polysaccharidic and ethanolic fractions. Food Chemistry 126(2), 610-616. Doi 10.1016/j.foodchem.2010.11.063.

Velioglu Z, Urek RO. 2015 - Optimization of cultural conditions for biosurfactant production by Pleurotus djamor in solid state fermentation. Journal of Bioscience and Bioengineering 120(5), 526-531. Doi 10.1016/j.jbiosc.2015.03.00.

Vital ACP, Goto PA, Hanai LN, Gomes-da-Costa SM, de Abreu-Filho BA, Nakamura CV, Matumoto-Pintro PT. 2015 - Microbiological, functional and rheological properties of lowfat yogurt supplemented with Pleurotus ostreatus aqueous extract. LWT - Food Science and Technology 64(2), 1028-1035. Doi 10.1016/j.lwt.2015.07.003.

Wang D, Sakoda A, Suzuki M. 2001 - Biological efficiency and nutritional value of Pleurotus ostreatus cultivated on spent beer grain. Bioresource Technology 78(3), 293-300. Doi 10.1016/s0960-8524(01)00002-5. PMID: 11341691.

Wang H, Gao J, Ng TB. 2000 - A new lectin with highly potent antihepatoma and antisarcoma activities from the oyster mushroom Pleurotus ostreatus. Biochemical and Biophysical Research Communications 275(3), 810-816. Doi 10.1006/bbrc.2000.3373. PMID: 10973803.

Wang H, Ng TB. 2001 - Pleureryn, a novel protease from fresh fruiting bodies of the edible mushroom Pleurotus eryngii. Biochemical and Biophysical Research Communications 289(3), 750-755. Doi 10.1006/bbrc.2001.6037. PMID: 11726212.

Wang H, Ng TB. 2004 - Eryngin, a novel antifungal peptide from fruiting bodies of the edible mushroom Pleurotus eryngii. Peptides 25(1), 1-5. Doi 10.1016/j.peptides. PMID: 15003349.

Wang HX, Ng TB. 2000 - Isolation of a novel ubiquitin-like protein from Pleurotus ostreatus mushroom with anti-human immunodeficiency virus, translation-inhibitory, and ribonuclease activities. Biochemical and Biophysical Research Communications 276(2), 587-593. Doi 10.1006/bbrc.2000.3540. PMID: 11027517.

Wang JC, Hu SH, Liang ZC, Yeh CJ. 2005 - Optimization for the production of water-soluble polysaccharide from Pleurotus citrinopileatus in submerged culture and its antitumor effect. Applied Microbiology and Biotechnology 67(6), 759-766. Doi 10.1007/s00253-004-1833-x. PMID: 15703910.

Wani BA, Bodha RH, Wani AH. 2010 - Nutritional and medicinal importance of mushrooms (Review). Journal of Medicinal Plants Research 4(24), 2598-2604. Doi 10.5897/JMPR09.565.

Wan-Rosli WI, Solihah MA, Mohsin SSJ. 2011 - On the ability of oyster mushroom (Pleurotus sajor-caju) conferring changes in proximate composition and sensory evaluation of chicken patty. International Food Research Journal 18, 1463-1469.

Wan-Rosli WI, Solihah MA. 2012 - Effect on the addition of Pleurotus sajor-caju (PSC) on physical and sensorial properties of beef patty. International food research journal 19, 993999.

Weng TC, Yang YH, Lin SJ, Tai SH. 2010 - A systematic review and meta-analysis on the therapeutic equivalence of statins. Journal of Pharmacology and Experimental Therapeutics 35(2), 139-151. Doi 10.1111/j.1365-2710.2009.01085.x. PMID: 20456733.

Wong JH, Ng TB, Jiang Y, Liu F. 2010 - Purification and characterization of a Laccase with inhibitory activity toward HIV-1 reverse transcriptase and tumor cells from an edible mushroom (Pleurotus cornucopiae). Protein and peptide letters Abbreviation 17(8), 1040 1047. Doi 10.2174/092986610791498966. PMID: 19807674.

Wong S, Wong K, Chiu L, Cheung P. 2007 - Non-starch polysaccharides from different developmental stages of Pleurotus tuber-regium inhibited the growth of human acute 
promyelocytic leukemia HL-60 cells by cell-cycle arrest and/or apoptotic induction. Carbohydrate Polymers 68(2), 206-217. Doi 10.1016/j.carbpol.2006.12.018.

Wu JY, Chen CH, Chang WH, Chung KT. 2011 - Anti-cancer effects of protein extracts from Calvatia lilacina, Pleurotous ostreatus and Volvariella volvacea. Evidence-Based Complementary and Alternative Medicine 2011, 1-10. Doi 10.1093/ecam/neq057.

Yang H, Shu Y. 2015 - Cadmium transporters in the kidney and cadmium-induced nephrotoxicity. International Journal of Molecular Sciences 16(1), 1484-1494. Doi 10.3390/ijms16011484. PMID: 25584611; PMCID: PMC4307315.

Yang JH, Lin HC, Mau JL. 2001 - Non-volatile taste components of several commercial mushrooms. Food Chemistry 72(4), 465-471. Doi 10.1016/s0308-8146(00)00262-4.

Yang JH, Lin HC, Mau JL. 2002 - Antioxidant properties of several commercial mushrooms. Food Chemistry 77(2), 229-235. Doi 10.1016/s0308-8146(01)00342-9.

Yang QT, Jong SC, Li XY, Zhou JX, Chen RT. 1992 - Antitumor and immunomodulating activities of the polysaccharopeptied-peptied (PSP) of Coriolus versicolor. Immunopharmacology and Immunotoxicology 12, 29-34.

Yang Z, Xu J, Fu Q, Fu X. 2013 - Antitumor activity of a polysaccharide from Pleurotus eryngii on mice bearing renal cancer. Carbohydrate Polymers 95(2), 615-620. Doi 10.1016/j.carbpol.2013.03.024. PMID: 23648020.

Zhang M, Cheung PC, Ooi VE, Zhang L. 2004 - Evaluation of sulfated fungal beta-glucans from the sclerotium of Pleurotus tuber-regium as a potential water-soluble anti-viral agent. Carbohydrate Research 339(13), 2297-2301. Doi 10.1016/j.carres.2004.07.003. PMID: 15337458.

Zhang M, Cheung PC, Zhang L. 2001 - Evaluation of mushroom dietary fiber (nonstarch polysaccharides) from sclerotia of Pleurotus tuber-regium (Fries) singer as a potential antitumor agent. Journal of Agricultural and Food Chemistry 49(10), 5059-5062. Doi 10.1021/jf0102281. PMID: 11600066.

Zhang M, Zhang L, Wang Y, Cheung PC. 2003 - Chain conformation of sulfated derivatives of beta-glucan from sclerotia of Pleurotus tuber-regium. Carbohydrate Research 338(24), $2863-$ 2870. Doi 10.1016/j.carres.2003.08.013. PMID: 14667707.

Zhiming F, Liu Y, Zhang Q. 2016 - A Potent Pharmacological Mushroom: Pleurotus eryngii. Fungal Biology and Biotechnology 6, 139. Doi 10.4172/2165-8056.1000139.

Zhou S, Ma F, Zhang X, Zhang J. 2016 - Carbohydrate changes during growth and fruiting in Pleurotus ostreatus. Fungal Biology 120(6-7), 852-861. 